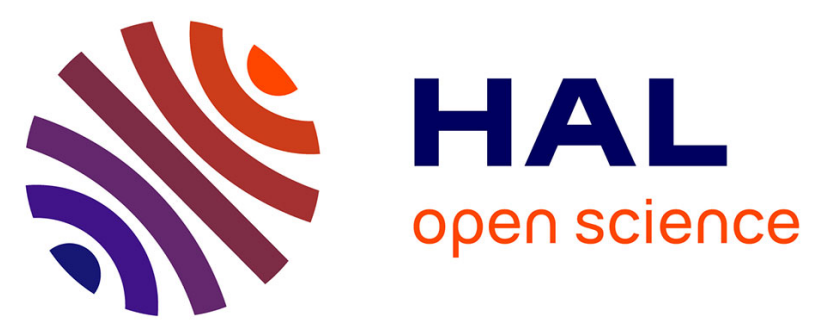

\title{
Skeletal quartz and dendritic biotite: Witnesses of primary disequilibrium growth textures in an alkali-feldspar granite
}

Pierre Barbey, François Faure, Jean-Louis Paquette, Karine Pistre, Cyrille Delangle, Jean-Paul Gremilliet

\section{To cite this version:}

Pierre Barbey, François Faure, Jean-Louis Paquette, Karine Pistre, Cyrille Delangle, et al.. Skeletal quartz and dendritic biotite: Witnesses of primary disequilibrium growth textures in an alkali-feldspar granite. Lithos, 2019, 348-349, pp.105202. 10.1016/j.lithos.2019.105202 hal-02328268

\section{HAL Id: hal-02328268 \\ https://hal.uca.fr/hal-02328268}

Submitted on 21 Dec 2021

HAL is a multi-disciplinary open access archive for the deposit and dissemination of scientific research documents, whether they are published or not. The documents may come from teaching and research institutions in France or abroad, or from public or private research centers.
L'archive ouverte pluridisciplinaire HAL, est destinée au dépôt et à la diffusion de documents scientifiques de niveau recherche, publiés ou non, émanant des établissements d'enseignement et de recherche français ou étrangers, des laboratoires publics ou privés.

\section{(ㅇ)(1) $\$$}

Distributed under a Creative Commons Attribution - NonCommerciall 4.0 International 


\section{Skeletal quartz and dendritic biotite: witnesses of primary disequilibrium}

\section{2 growth textures in an alkali-feldspar granite}

3

4

5 Pierre Barbey $^{1 *}$, François Faure ${ }^{1}$, Jean-Louis Paquette ${ }^{2}$, Karine Pistre $^{3}$, Cyrille Delangle ${ }^{4}$,

6 Jean-Paul Gremilliet ${ }^{4}$

7

8

$9 \quad{ }^{1}$ Université de Lorraine, CNRS, CRPG, F-54000 Nancy, France

$10{ }^{2}$ Université Clermont Auvergne, CNRS, IRD, OPGC, Laboratoire Magmas et Volcans, F-

1163000 Clermont-Ferrand, France

$12{ }^{3}$ Université de Lorraine, CNRS, GeoRessources, F-54000 Nancy, France

$13{ }^{4}$ Centre Terrae Genesis, F-88120 Le Syndicat, France

14

15

16

17

18

19

20

21

22

23

24

25

26

$27 *$ Corresponding author:

28 E-mail: pierre.barbey@univ-lorraine.fr

29 


\section{$30 \quad$ Highlights}

31 Cathodoluminescence imaging reveals the presence of two generation of quartz

32 The first generation corresponds to both rounded and skeletal grains

33 The second generation (overgrowths) led to partly equilibrated texture

34 Biotite shows variable morphology, including skeletal and dendritic habits

35 These textures are interpreted to result from primary disequilibrium growth 36

37 


\section{Abstract}

We describe a case of S-type alkali-feldspar granite (quartz/K-feldspar/plagioclase/ biotite/garnet 30/35/20/13/2 vol. \%) showing skeletal and dendritic textures. It consists of three nested units distinguishable by the size of biotite crystals: a first-emplaced unit characterized by small biotite flakes $(0.4-9 \mathrm{~mm})$; a second unit with $\mathrm{cm}$-sized biotite platelets (0.3-28 mm) outlining a syn-magmatic foliation; and a third unit formed of large biotite plates $(0.7-850 \mathrm{~mm})$ showing dendritic and radial growth patterns.

Quartz occurs mostly as rounded to euhedral grains, but also shows complex shapes (serrated outline, re-entrants, etc.). Cathodoluminescence imaging reveals that grains consist of both rounded and skeletal bluish cores (quartz-1) rimmed by reddish overgrowths (quartz2) that lead locally to the coalescence of neighbouring grains and equilibrated texture. Biotite is poikilitic enclosing dominantly quartz grains but also in lesser amount plagioclase and garnet. In the third unit, biotite shows textures typical of dendritic growth (bifurcating, radiating or branching structures, skeletal core). Plagioclase $\left(\mathrm{An}_{\leq 25}\right)$ occurs as small euhedral to subhedral grains scattered in the matrix or forming glomerophyric aggregates. K-feldspar (Or74-100) mostly forms an almost equilibrated mosaic of anhedral perthitic crystals; it also appears in association with albite as a secondary phase replacing plagioclase. The crystallization sequence started with garnet, then proceeded with quartz, plagioclase, biotite and K-feldspar, ended with cordierite, and was followed by subsolidus reequilibration.

The variability in size and morphology of quartz and biotite is interpreted in terms of variable undercooling depending on temperature of the host-rocks and on more or less intense degassing of magma batches with variable melt water content. Here, rapid crystallization prevented significant textural reequilibration and allowed the initial crystallization textures of quartz to be preserved. Overall, this study shows that behind the common "coarse-grained" texture of quartz in granite, subsist primary disequilibrium crystallization textures. 
65 Keyword: texture; dendritic growth; granite; undercooling 66 


\section{Introduction}

68 During their thermal evolution, igneous rocks tend to approach textural equilibrium to minimize excess surface energy. This is more particularly visible in plutonic rocks owing to mass redistribution within the crystal pile (e.g. Lesher and Walker, 1988), which leads to textural coarsening (e.g. Higgins, 2011), a process well illustrated by the mafic layered igneous complexes (e.g. Cawthorn, 1996). Even though the thermal history and related textural maturity can, to some extent, be deciphered from the study of dihedral angles (Holness, 2005; Holness et al., 2007a, 2007b, 2007c) or crystal size distribution (Cashman and Marsh, 1988; Higgins, 2011; Magee et al., 2010; Marsh, 1988), studies of igneous rocks are often facing with the issue to know to what extent the textures we observe are representative of the initial stages of crystallization.

Experimental works led to a better understanding of crystal morphology in relation with the dynamics of magma crystallization in rapidly cooled rocks (e.g. Lofgren, 1980). For instance, shapes of plagioclase in basalts or of olivine in spinifex-textured komatiites, first attributed to quenching, was shown to be related to cooling rates (Donaldson, 1976, 1982; Lofgren, 1974; Lofgren \& Donaldson, 1975). Later, Faure et al. (2003, 2006) determined experimentally the respective role of undercooling, cooling rate and thermal gradient on the shape and orientation of olivine crystals. Phosphorus zoning patterns in olivine from diverse volcanic rocks and meteorites have also revealed that olivine phenocrysts are cored by dendrites (Libourel et al., 2018; Milman-Barris et al., 2008; Welsch et al., 2013, 2014), a characteristic attributed to primary variations in crystal growth rate (Milman-Barris et al., 2008). This observation has been extended to olivine from Mid-Atlantic Ridge gabbro and from mafic-ultramafic intrusions (Welsch et al., 2014; Xing et al., 2017). This led Welsch and co-workers to conclude that diffusion-controlled crystal growth is an important feature of primary textures in igneous rocks. Others authors also emphasized that high supersaturation 
and high growth rate are not uniquely driven by rapid cooling, but could also be enhanced by shift in the liquidus temperatures related to change in melt water content (Donaldson, 1974; Vernon, 1985; Almeev et al., 2007; Médard and Grove, 2008).

Concerning silicic plutonic rocks, crystallization experiments show that quartz exhibits different morphologies as a function of the degree of undercooling (MacLellan and Trembath, 1991; Swanson and Fenn, 1986). At small $\Delta \mathrm{T}$, quartz develops subhedral to euhedral shapes by interface-controlled growth mechanisms; whereas at larger $\Delta \mathrm{T}$, diffusion-controlled growth mechanisms promote the formation of skeletal shapes in relation with compositional gradient at the melt-crystal interface. Under longer experimental runs, skeletal quartz becomes rounded by the reduction in the degree of faceting and the partial infilling of skeletal crystals. Besides, preservation of primary compositional growth patterns in quartz has been found in dacites and rhyolites (Ackerson et al., 2018; Ahmed, 2011; Götze et al., 2001; Seitz et al., 2016; Watt et al., 1997); and disequilibrium growth textures (skeletal and dendritic) are also known in some specific silicic plutonic rocks, such as pegmatites (e.g. Frindt and Haapala, 2004; Haapala and Lukkari, 2005; Ivanov and Grozdanov, 2001; London, 2009; Müller et al., 2002; Shannon et al., 1982; Swanson and Fenn, 1986) and orbicular granites (e.g. Decitre et al., 2002; Smillie and Turnbull, 2014).

Overall, it can be expected that the common "coarse-grained" texture of granite might conceal primary disequilibrium crystallization textures partly hidden (if not erased) by the subsequent thermal evolution. The aim of this study is to address this issue from an interesting case of alkali-feldspar granite. After description of phase assemblages and chemical compositions, we focus on the characterization of textures to demonstrate that this granite preserves primary disequilibrium growth textures recorded in the morphology of quartz and biotite. 


\section{Samples}

118 The granite studied here is located in the Central Vosges domain, eastern France (Fluck et al., 119 1991; Skrzypek et al., 2014). The outcrop, ca. $250 \mathrm{~m}$ long, is located along the road D42, 2

$120 \mathrm{~km}$ to the NW of Eloyes (4806’21.50” N - 06'35’30.50” E). A cross-section (Fig. 1) shows

121 that the alkali-feldspar granite body forms the most part of the road cut, being bounded

122 (faulted contacts) to the NW by intrusive coarse-grained porphyritic granite (Remiremont

123 granite belonging to the Central Vosges granite association; Tabaud et al., 2015), and to the

124 SW by migmatitic biotite gneisses (metatexites to diatexites). Therefore, its exact extension

125 and geometry, seemingly a dike, remain unknown. A presentation of its geological context

126 and emplacement age is given in Supplementary material SM.1.

127 The granite corresponds to a pale pink rock, consisting of a fine- to medium-grained

128 quartzofeldspathic matrix with limited amounts of ferromagnesian minerals. Considering the

129 matrix grain size (average of ca. $0.25 \mathrm{~mm}$ ), the rock appears to be at the limit between granite

130 and microgranite according to the grain size classification of Gillespie \& Styles (1999). The

131 matrix consists of quartz (30-40 vol.\%), K-feldspar (30-40 vol. \%) and plagioclase (20-25

132 vol. \%), whereas the ferromagnesian mineral phases consist of garnet ( $\leq 7$ vol. \%), biotite (5-

13315 vol. \%) and scarce late-magmatic cordierite ( \pm tourmaline). Accessory minerals are zircon,

134 monazite, ilmenite and Ti-oxide. Secondary phases are muscovite, albite and K-feldspar

135 replacing primary feldspars; green biotite, chlorite, and hematite replacing garnet; and chlorite

136 and prehnite replacing biotite. The variable size of biotite led us to distinguish three magmatic

137 units (Fig. 1):

138 - Unit-1 forms the external parts of the igneous body. It contains medium-grained,

139 randomly distributed, biotite flakes outlining a faint syn-magmatic fabric (Fig. 2a, b). The

140 grain size of the matrix lies mostly between 0.3 and $0.6 \mathrm{~mm}$, though ranging from $0.05 \mathrm{~mm}$ to

$141 \quad 1.7 \mathrm{~mm}$ for the largest K-feldspar crystals (Fig. 2c). 
- Unit-2 forms the core of the body. Biotite is mostly medium- to coarse-grained and

143 outlines a widespread syn-magmatic foliation (Fig. 3a-c), trending ENE-WSW, steeply

144 dipping (ca. $80^{\circ}$ ) and locally accompanied with a weak lineation. The grain size of the matrix

145 lies between 0.3 and $0.8 \mathrm{~mm}$ (Fig. 3d). Small mafic and autolithic enclaves $(6-8 \mathrm{~cm}$ in

146 diameter), wrapped up by the foliation, are observed locally (Fig. 3c).

147 - Unit-3 corresponds chiefly to a ca. 2-metre-thick dyke-like body, but also to scarce small

148 veins within Unit-2. It is characterized by the presence of large biotite crystals showing a

149 specific textural organization (Fig. 4a-c) described farther. The grain size of the matrix lies

150 mostly between 0.2 and $0.6 \mathrm{~mm}$ (Fig. 4d), though some K-feldspar crystals may reach $1.5 \mathrm{~cm}$

151 in length. A faint foliation occurs locally in connection with small shear-zones.

152 Internal contacts between the three units are sharp with no chilled margin and no crystals

153 nucleation on the contacts; they are marked mainly by change in the biotite size and locally by

154 loss of the fabric (between Unit-2 and Unit-3). Textures and mineral compositions are

155 presented in more detail in section 4.

\section{3. Whole-rock compositions}

158 Whole-rock major and trace element compositions are given in Table 1 and analytical

159 conditions in the Supplementary material SM.2. The rock is granitic $\left(69.7<\mathrm{SiO}_{2}<75.2 \mathrm{wt}\right.$.

$160 \%$ ), with a normative composition classifying it as alkali-feldspar granite ( $Q^{\prime}=34.9-42.4$;

161 ANOR $=0.5-5.4$ ) according to Streckeisen and Le Maitre (1979). It is peraluminous

$162\left(\left[\mathrm{Al}_{2} \mathrm{O}_{3}\right] /\left[\mathrm{CaO}+\mathrm{Na}_{2} \mathrm{O}+\mathrm{K}_{2} \mathrm{O}\right]=1.22-1.38\right)$, with $\mathrm{Mg} \#$ values ranging from 33 to 41 (total iron

163 as $\mathrm{Fe}^{2+}$ ), plotting close to the ferroan line in the classification diagram of Frost et al. (2001)

164 (not shown). Trace element contents are low, with the notable exception of $\mathrm{Ba}, \mathrm{Rb}$ and $\mathrm{Zr}$

165 (331-689, 211-264 and 72-149 ppm, respectively). Trace element discriminant ratios

166 (Whalen et al., 1987) corroborate its S-type chemistry $(\mathrm{Zr}+\mathrm{Nb}+\mathrm{Ce}+\mathrm{Y}=139-246 \mathrm{ppm}$; 
$\left.10^{4 *} \mathrm{Ga} / \mathrm{Al}=2.1-2.4\right)$, corresponding to low-Ca unfractionated granite $\left(\mathrm{X}_{\mathrm{Sr}}<0.15\right.$ and $\mathrm{X}_{\mathrm{Rb}}<$

168 0.35) according to the nomenclature of El Bouseily and El Sokkary (1975). Zircon saturation thermometry (Watson and Harrison, 1983) yields temperatures in the range $740-800^{\circ} \mathrm{C}$. Sr and $\mathrm{Nd}$ isotopic compositions (Table 2) show ${ }^{87} \mathrm{Sr} /{ }^{86} \mathrm{Sr}_{(330 \mathrm{Ma})}$ initial ratio of $0.726, \varepsilon \mathrm{Nd}_{(330 \mathrm{Ma})}$ value of -8.2 , and $\mathrm{Nd}$ model age ( $\mathrm{T}_{\mathrm{DM}}$ ) of $1865 \mathrm{Ma}$ consistent with zircon $\mathrm{U}-\mathrm{Pb}$ data attesting to the presence of inherited core at $1.9 \mathrm{Ga}$ (see Supplementary material SM.1).

173 Multi-element plot normalized to Primitive Mantle (Fig. 5a) shows depletion in Ba, U, Th, $174 \mathrm{Ta}, \mathrm{Nb}, \mathrm{Sr}, \mathrm{Eu}$ and Ti. K/Rb (198-254) and Y/Ho (27-29) ratios are similar to values of 175 common igneous rocks, and the $\mathrm{Zr} / \mathrm{Hf}$ ratio (33-37) is close to that of most terrestrial rocks 176 ( 38). $\mathrm{Nb} / \mathrm{Ta}$ ratio (7-14, with the exception of Unit-1 with values at 19 and 23) compared to $177 \mathrm{Zr} / \mathrm{Hf}$ ratio corresponds to that of barren granites (Ballouard et al., 2016). However, the K/Ba 178 (73-194), $\mathrm{La} / \mathrm{Nb}(1.7-5.3)$ and $\mathrm{La} / \mathrm{Ta}(19-123)$ ratios are significantly higher than those of 179 common magmatic rocks, suggesting non-CHARAC behaviour of $\mathrm{Ba}, \mathrm{Nb}$ and $\mathrm{Ta}$, and thus, 180 the possible effect of hydrothermal fluids (e.g. Bau, 1996; Jahn et al., 2001). Rare earth 181 elements (REE) normalized to chondrite (Fig. 5b) show moderately fractionated light REE $182\left([\mathrm{La} / \mathrm{Sm}]_{\mathrm{N}}=2.9-5.2\right)$, negative Eu anomalies $\left(\mathrm{Eu} / \mathrm{Eu}^{*}=0.3-0.7\right)$ and weakly fractionated 183 heavy REE $\left([\mathrm{Gd} / \mathrm{Yb}]_{\mathrm{N}}=0.6-0.8\right)$. The negative slope and concave-downward shape of heavy 184 REE, along with $\mathrm{t}_{3}$ parameter $\left(\left[\mathrm{Tb} / \mathrm{Tb}^{*} \times \mathrm{Dy} / \mathrm{Dy}^{*}\right]^{0.5} ;\right.$ Irber, 1999) around 1.01-1.13, could 185 suggest a possible weak tetrad effect. Nevertheless, the $T E_{1,3}$ parameter $\left(\left[\mathrm{t}_{1} \times \mathrm{t}_{3}\right]^{0.5}\right.$, with $\mathrm{t}_{1}=$ $186\left(\left[\mathrm{Ce} / \mathrm{Ce} * \times \operatorname{Pr} / \mathrm{Pr}^{*}\right]^{0.5}\right.$; Irber, 1999) remains low (1.00-1.09) compared to the minimum value 187 (1.1) generally considered to be significant of the tetrad effect (Irber, 1999).

\section{Textures and mineral compositions}


In optical microscopy quartz appears mostly as euhedral (sub-hexagonal or quadrangular) to

192 subhedral (rounded) grains. Nevertheless, more complex shapes are observed: (i) grains

193 showing serrated outline resembling incipient branching arms (Fig. 6a); (ii) crystals with

194 equilibrated grain boundaries (Fig. 6b); (iii) triangular extensions and thin films (in optical

195 continuity with a main quartz grain) pervading feldspar-feldspar or feldspar-biotite grain

196 boundaries (Fig. 6c, d); (iv) crystals with rounded re-entrants (Fig. 6e) as commonly observed

197 in high-cooling magmas (rhyolite); and (v) anhedral grains in interstitial position probably

198 pseudomorphing the residual melt-filled porosity (Fig. 6f).

199 Cathodoluminescence imaging reveals that quartz grains have an internal structure

200 consisting of a bluish core commonly surrounded by reddish overgrowth. The cores

201 correspond to more or less rounded to elliptical grains with regular to wavy outlines (Fig. 7a),

202 or to skeletal grains with jagged outlines (Fig. 7b), branching structures (Fig. 7c) and hollow

203 cores (Fig. 7a, d). Overgrowths are not systematically present and do not always form a

204 continuous rim all around cores (e.g. Fig. 7a, b); they commonly lead to the coalescence of

205 neighbouring grains, giving rise locally to equilibrated granoblastic texture (Fig. 7e). Textural

206 relationships between quartz and biotite show unambiguously that cores predate biotite

207 crystallization, whereas overgrowths formed synchronously with biotite. This is indicated by

208 (i) blue cores directly in contact with biotite without overgrowth; (ii) space between two blue

209 cores filled with quartz-2 and biotite; (iii) thin red quartz outgrowths along the cleavage of

210 biotite; and (iv) reddish quartz forming symplectitic intergrowths with biotite, for some of

211 them in continuity with the overgrowth surrounding bluish quartz grains (Fig. 7f).

212 Quartz grain size varies from one unit to another. Sizes were measured in thin section

213 considering the long axes of the whole grains, even though this undoubtedly introduces a bias

214 due the presence of overgrowths. Nevertheless, the small thickness of these overgrowths, their

215 non-systematic occurrence and their similarity in all units lead us to consider that the size 
variation of all grains is controlled by the size variation of cores. In Unit-1, quartz grain size

217 ranges from 0.04 to $0.6 \mathrm{~mm}$ with a median at $0.14 \mathrm{~mm}$ (Fig. 8a). In Unit-3, a similar range

218 (0.05 to $0.6 \mathrm{~mm}$ ) is observed, but the sizes appear a little more homogeneous with ca. $57 \%$ of

219 the grains between 0.15 and $0.25 \mathrm{~mm}$ (Fig. 8b, c). In Unit-2, quartz population shows higher

220 dispersion, with sizes ranging from 0.05 to $1.3 \mathrm{~mm}$ and medians $\geq 0.24 \mathrm{~mm}$ (Fig. $8 \mathrm{~d}-\mathrm{f}$ ). On

221 the whole, although the average grain size does not significantly differ from one unit to the

222 other, we note that the histograms of size distribution differ in each unit, the standard

223 deviation is higher in the Unit-2 attesting to its greater heterogeneity, and the proportion of

224 grains with a size higher than $0.25 \mathrm{~mm}$ markedly increases from Unit-1 (ca. $15 \%$ ) to Unit-3

225 (ca. $25 \%)$ and Unit-2 (30-55\%).

\subsection{Garnet}

228 Garnet occurs as euhedral to subhedral rounded grains (Fig. 9a, b), with size ranging between 0.4 and $2.0 \mathrm{~mm}$. It may occur as inclusion in feldspar or in biotite (in this case, it may show partial retrogression; Fig. 9c). Garnet corresponds dominantly to a binary solid solution of

231 almandine $(77.6 \pm 3.6 \mathrm{~mol} . \%$ on average $)$ and pyrope $(15.7 \pm 3.8 \%)$, with limited amounts of

232 spessartite $(4.3 \pm 2.0 \%)$ and grossularite $(2.4 \pm 0.4 \%)$. It is slightly more Mg-rich in the

233 Unit-3 compared to the other units (Fig. 10a), whereas garnet from Unit-1 has a slightly

234 lower content of spessartite + grossularite.

\subsection{Biotite}

The common feature of biotite in all units is to be poikilitic (Fig. 11a), enclosing dominantly quartz grains but also in much smaller amount plagioclase and garnet. In Unit-1, biotite occurs as small rounded flakes to slightly larger anisometric crystals (Fig. 2a, b) with rather

240 homogeneous sizes, mostly $\leq 5 \mathrm{~mm}$ (range $0.4-9 \mathrm{~mm}$, Fig. 12a). In Unit-2, biotite occurs as 
241 larger platelets parallel or at high angle to the fabric (Fig. 3d). It is more heterogeneous in size

242 (Fig. 3a), with length ranging from 0.3 to $28 \mathrm{~mm}$ (Fig. 12b); this heterogeneity being

243 enhanced by the presence of zones showing higher grain size (Fig. 3c). Some of the largest

244 crystals display branching bifid structure and hollow cores (Fig. 11b and 11e, respectively). In

245 Unit-3, biotite forms a network of large plates arranged at high angle to each other (Fig. 4b,

246 c), with sizes ranging from 0.7 to $850 \mathrm{~mm}$ (Fig. 12c). Its shape encompasses rounded or

247 slightly anisometric millimetre-sized flakes similar to those of the former units, to large

248 blades with width/length ratio around 0.4 (Fig. 4a). Radial growth patterns (Fig. 4b, c) and

249 dendritic shapes (Fig. 11c, d) are characteristic of biotite in this unit. It also shows hollow

250 cores filled with feldspathic material between thin biotite platelets in crystallographic

251 continuity with the main crystal (Fig. 11f). There is a clear difference in the histograms of

252 biotite size distribution between the three units: in Unit-1 the distribution is tightened around

$2531.4 \mathrm{~mm}$, while in Unit-2 it is more heterogeneous with an average around $4.2 \mathrm{~mm}$; histogram

254 of Unit-3 is given only for information, as it has very little significance due to the branching

255 nature and stronger anisotropic shape of the biotite plates.

256 Biotite is slightly magnesian (Fig. 10b), with $\mathrm{X}_{\mathrm{Mg}}$ ratios ranging from 0.30 to $0.49(0.41 \pm$

2570.04 on average); $\mathrm{TiO}_{2}$ contents are mostly around $3.1 \%$ (range $1.07-4.42$ wt. \%); and $\mathrm{Al}^{\mathrm{VI}}$

258 contents range from 0.54 to 1.60 atoms per formula unit (apfu). Its high total $\mathrm{Al}$ content $\left(\mathrm{Al}_{\text {tot }}\right.$

$259=3.1-4.4 \mathrm{apfu})$ with respect to $\mathrm{Mg}(1.2-2.2 \mathrm{apfu})$ is consistent with the peraluminous

260 character of the host-rock. Secondary green biotite crystals, mainly developed at the expense

261 of garnet, depart from this compositional field, with higher $\mathrm{Al}^{\mathrm{VI}}$ values (0.9-1.6 compared to

$262 \leq 0.9)$ and lower $\mathrm{TiO}_{2}$ contents (mostly $\leq 1.0 \mathrm{wt}$. \% compared to $3.1 \%$ on average). 
265 Cordierite occurs as scarce centimetre-sized cockades and streaks surrounded by a biotite-

266 free, quartzofeldspathic halo; cordierite includes numerous quartz grains but is free of

267 feldspars, and overall presents characteristics similar to late-magmatic cordierite reported

268 from other S-type granites (e.g. Barbey et al., 1999). It also contains a few grains of

269 tourmaline. These structures overprint the syn-magmatic fabric carried by biotite, indicating

270 that cordierite grew at its expense at the end of the crystallization sequence.

271 Cordierite is deeply retrogressed into pinite and we were not able to obtain reliable major

272 element composition. Tourmaline shows $\mathrm{X}_{\mathrm{Mg}}$ values around $0.48-0.50$.

274 4.5. Feldspars

275 They correspond dominantly to K-feldspar and in lesser proportion to sodic plagioclase.

276 Plagioclase occurs as small euhedral to subhedral grains (mostly ca. $0.1-0.2 \mathrm{~mm}$ ), scattered in

277 the matrix (Fig. 13a), forming locally glomerophyric aggregates (Fig. 13b), or overgrown on

278 quartz grains (Fig. 13f). Unaltered grains correspond to oligoclase/andesine (An $\leq 25 ;$ Fig. 10a).

279 Albite is a widespread secondary mineral phase, which occurs as thin rims around

280 plagioclase, or veinlets along grain boundaries between the matrix K-feldspar grains (Fig.

281 13a); it also replaces primary plagioclase crystals, forming patchy zoning in association with

282 K-feldspar and muscovite (Fig. 13c, f).

283 K-feldspar, the main interstitial phase, may occur as subhedral to euhedral crystals (Fig.

284 13d), but in most cases, it is anhedral and forms an almost equilibrated mosaic between quartz

285 and plagioclase grains (Fig. 13a). It may be perthite-free, but more commonly contains

286 variable proportions of exsolutions, some crystals being strongly perthitic (Fig. 13e). It also

287 occurs as a secondary phase forming thin rims around plagioclase crystals (Fig. 13f), or

288 patches partly replacing them. K-feldspar has a composition ranging from $\mathrm{Or}_{74} \mathrm{Ab}_{25} \mathrm{An}_{01}$ solid

289 solution for the magmatic feldspar to the orthoclase end-member for the secondary one (Fig. 
10c). Within a single grain, the composition varies very weakly, with $\mathrm{Na}_{2} \mathrm{O}$ contents ranging

291 from 0.3 to 1.2 wt.\%. Analysis of a few exsolutions shows An-rich compositions (Or ${ }_{16-}$ ${ }_{26} \mathrm{Ab}_{61-68} \mathrm{An}_{14-16)}$.

\section{Discussion}

295 Whole-rock geochemical data show that the studied alkali-feldspar granite derives from 296 parent magma generated by partial melting of an old recycled continental crust, in agreement with the regional geodynamic reconstruction (Skrzypek et al., 2014). Its composition is close to that of S-type felsic rocks used in crystallization experiments (e.g. Clemens and Birch, 2012; Scaillet et al., 1995) (Table 1), even though its rather high peraluminosity could be

300 partly related to the alteration of feldspars in sericite. However, the small compositional

301 heterogeneities ( $\mathrm{Si}, \mathrm{Fe}, \mathrm{REE}, \mathrm{Th}, \mathrm{U}, \mathrm{Nb}$ and $\mathrm{Ta}$ ) observed within and in between units, and their distinct textures seemingly implying distinct melt water contents (see below, section 5.3), suggest that the three units derive from three different magma batches with distinct water content, and probably represent different stages of differentiation of a common parent magma.

\subsection{Crystallization sequence}

307 Defining the sequence of crystallization is not straightforward from textural relationships.

308 Inclusion of garnet as minute grains in plagioclase and as more or less retrogressed grains in

309 biotite suggests that it is probably one of the first phase on the liquidus. The common

310 occurrence of plagioclase as euhedral crystals overgrown on quartz grains, or in interstitial

311 position between them suggest that this phase started crystallizing after quartz. The

312 appearance of biotite postdates quartz, though their relationships are a little more complex in

313 detail (see next subsection). Timing of crystallization of biotite and plagioclase is to some

314 extent ambiguous. The presence of scarce plagioclase inclusions within biotite could suggest 
that the former started to crystallize first; however, it is more likely that these two phases

316 followed closely each other. K-feldspar, the last magmatic phase to crystallize, mostly forms a 317 granoblastic mosaic of crystals embedding all the other minerals, even though it can be

318 locally euhedral, suggesting local crystallization without interference with neighbouring

319 grains. This sequence ends with the scarce growth of cordierite ( \pm tourmaline) at the expense

320 of biotite, and then partial subsolidus reequilibration (albite, chlorite, etc.).

From previous works (Latouche et al., 1992; Rey et al., 1989; Skrzypek et al., 2012) and

$\mathrm{U}-\mathrm{Pb}$ zircon data indicating that the alkali-feldspar granite predates the Central Vosges granite association (Supplementary material SM.1), a poorly constrained 200-500 MPa range could be envisaged for the conditions of emplacement. Temperatures estimated from zircon saturation thermometry $\left(740-800^{\circ} \mathrm{C}\right)$ are too low to be considered those of the magma at the time of its emplacement, especially since part of the zircon is inherited. Although the high variance of the phase assemblage does not allow a precise reconstruction of the $\mathrm{P}-\mathrm{T}$ conditions of emplacement, we attempted a comparison with the experimental results obtained by Clemens and Birch (2012) on the Rubicon Ignimbrite, compositionally close to our granite. From their $\mathrm{T}-\mathrm{X}^{\mathrm{Fl}} \mathrm{H}_{2} \mathrm{O}$ phase diagrams it appears that the early crystallization of garnet in the absence of orthopyroxene, cordierite and biotite implies crystallization pressure around $500 \mathrm{MPa}$ from hydrated magma, and this seems to occur in a restricted field $(800<\mathrm{T}$ $\left.<880^{\circ} \mathrm{C}, 0.4<\mathrm{X}^{\mathrm{Fl}} \mathrm{H}_{2} \mathrm{O}<0.8\right)$. Their results also indicate that (i) the stability field of cordierite expands widely with decreasing pressures, and (ii) feldspars are the late phases to appear. Comparing our sequence of crystallization with these experimental data could suggest that crystallization started at pressure around $500 \mathrm{MPa}$ from a magma with significant melt water content, but took place mainly at lower pressure to account for the early appearance of quartz and the late crystallization of cordierite. In fact, we should expect cordierite to appear earlier in the sequence, which is not the case; it cannot be excluded that its absence in the first 
steps could be due to inhibited nucleation as observed in experiments (Clemens and Birch,

341 2012). A last point is that the onset of plagioclase crystallization occurred before biotite and

$342 \mathrm{~K}$-feldspar, which is at odds with the experimental results showing that plagioclase is late in

343 the crystallization sequence. Nevertheless, in experiments on Himalayan leucogranite

344 (Scaillet et al., 1995) also compositionally close to our granite, plagioclase appears early,

345 suggesting that minor compositional differences may lead to inversion in the crystallization

346 order.

\subsection{Significance of the textures of quartz and biotite}

349 From the cathodoluminescence properties of quartz we consider that the bluish cores and

350 reddish overgrowths of quartz grains represent two successive growth stages. Indeed, studies

351 of quartz from igneous rocks (Götze et al., 2001; and references therein) suggest that $\mathrm{Al}$ (and

352 possibly $\mathrm{Ti}$ ) could play a role in the blue emission component, whereas the red component

353 (often observed in rims and cracks of crystals) would be related to lattice defects. Quartz-1

354 (bluish cores) predates biotite and corresponds to both skeletal crystals and rounded to

355 subhedral grains with a regular to wavy outline. Quartz-2 (reddish overgrowths) and biotite

356 crystallized synchronously as indicated by their symplectitic relationships (Fig. 7f). Growth of 357 quartz-2 resulted in the formation of rounded to euhedral grains from the skeletal cores, as 358 well as in grain coalescence and equilibrated textures by grain feeding along boundaries from 359 the melt. On the whole, the sharp contact between the two generations of quartz shown by CL 360 and their distinct textural position mark an abrupt change in growth conditions. This is 361 distinct from what is observed in olivine wherein P enrichment appears to reflect a continuous 362 decay in growth rate (e.g. Welsch et al., 2014).

363 The skeletal shapes of quartz-1 can be interpreted in two ways, either dissolution or 364 disequilibrium growth. Dissolution appears highly unlikely even though adiabatic 
decompression can lead to remelting of early crystallized assemblages (Johannes and Holtz, 1996), and this for two main reasons. First, quartz dissolution experiments in rhyolitic melts (Donaldson and Henderson, 1988) show that this process leads to round corners and edges, and overall to more compact morphologies, but not to sharp crystal edges as we observe (see also Swanson and Fenn, 1986). Secondly, if we rely on the phase relationships of the Rubicon ignimbrite, it appears that for a magma $\left(500 \mathrm{MPa}, 850^{\circ} \mathrm{C}, \mathrm{X}^{\mathrm{Fl}} \mathrm{H}_{2} \mathrm{O}=0.5\right)$ ascending adiabatically, quartz starts to crystallize only down to $200 \mathrm{MPa}$, i.e. close to the level of emplacement. We rather consider that the skeletal shapes result from diffusion-controlled growth as observed in crystallization experiments at high undercooling (Swanson and Fenn, 1986; MacLellan and Trembath, 1991). In addition, variation of the degree of undercooling during emplacement could account for the occurrence of both skeletal habits (early high supersaturation) and rounded grains with smooth outlines (subsequent decreasing undercooling). In any case, the skeletal shape of quartz-1, whatsoever resulting from dissolution or disequilibrium crystallization, can be considered as primary disequilibrium textures preserved behind the apparent "coarse-grained" texture.

It is worth of note that the CL image of Fig. 8b contains a quartz grain showing a hollow core with arms radiating towards its centre. This grain presents a sub-hexagonal section (faces are easily recognizable), thus not far from being orthogonal to the $c$ axis. This disposition seems therefore to indicate that the arms are radial with respect to this axis, which is in agreement with the experimental results of Swanson and Fenn (1986).

Looking at the quartz grain size in the three units (Fig. 8), it appears that its distribution in Unit-1 and Unit-2 are quite comparable, differing mainly by the average grain size and the 387 proportion of larger grains ( $15 \%$ in Unit-1 vs. 30-55 \% in Unit-2). This may simply result 388 from distinct cooling, due to the thermal state of the host rock. Compared to Unit-2, the histogram of Unit-3 differs by a limited population of small grains $(\leq 0.1 \mathrm{~mm})$ and a very 
restricted population of larger grains $(\sim 25 \% \geq 0.3 \mathrm{~mm})$ which is closer to that of Unit-1.

391 Although we cannot fully discard cutting effects, we consider that two processes may account

392 for this peculiar distribution. Firstly, the limited amount of small grains suggests coarsening

393 by Ostwald ripening probably mainly in favour of medium sizes since this process seems to

394 be only effective for small sizes (Cabane et al., 2001). This also implies that there was no

395 creation of new grains and, thus, that the nucleation of quartz has not been continuous.

396 Secondly, the restricted population of larger grains implies that coarsening was rapidly

397 impeded.

398 Textural relationships indicate that biotite postdates quartz-1 and possibly plagioclase,

399 while it is coeval with quartz-2. Furthermore, variation of its size and morphology from one

400 unit to the other suggests distinct nucleation and growth rates, and therefore distinct magma

401 supersaturation in each unit. More particularly, the large size of biotite crystals in Unit-3 and 402 their tendency to form radiating clusters (nucleation of several grains at a single site) implies 403 very limited nucleation. This precludes in situ differentiation of the three units from a unique 404 magma batch by fractional crystallization. We note that the morphology of biotite from Unit-3

405 resembles those of biotite from stockscheider pegmatites (see for example Haapala and 406 Lukkari, 2005; their Fig. 3c). However, the absence, in this unit and in the whole granite body 407 as well, of rhythmic mineralogical laminations, feldspar and quartz segregation, inward 408 gradual increase of crystal size and unidirectional growth texture from walls indicates that the 409 studied granite cannot be equated to pegmatite (for pegmatite features, see London and 410 Morgan, 2017), even though similar process may have been at work.

\section{$412 \quad$ 5.3. A possible crystallization scenario}

413 Some experimental results may help us in building an appropriate scenario. (1) As pointed out 414 by Swanson (1977) and Swanson and Fenn (1986), the nucleation of quartz is an abrupt 
415 process at high rates in granitic melts. (2) Ostwald ripening of quartz grains seems to be an 416 active process only at the end of nucleation event, becoming negligible when grains reach 417 millimetre size (Cabane et al., 2001). (3) At high undercooling (i.e. high supersaturation 418 conditions), crystal habit evolves towards skeletal and dendritic shapes, with radial growth 419 patterns (e.g. London, 2005; and references therein, for silicic rocks). More specifically, 420 London and Morgan (2017) show in their experiments that limited undercooling leads to fine421 grained disseminated crystals, whereas at high undercooling crystal evolves towards skeletal and radiating morphologies.

Considering that the three units correspond to three distinct batches from a common source, emplaced at the same level in the crust, the only two parameters that are likely to vary to account for distinct supersaturation in each unit at the site of emplacement, are (i) the temperature of the surrounding rocks, owing to the fact that the Unit-1 was emplaced in colder host-rocks while the Unit-2 and Unit-3 are nested in the preceding ones; and (ii) the volatile content of the melt and extent of degassing that may differ from one magma batch to the other. We therefore propose a crystallization scenario in three main steps.

(1) The first step common to all units corresponds to the onset of crystallization of garnet 431 from a hydrated silicic peraluminous melt under pressures of ca. $500 \mathrm{MPa}$ to avoid early crystallization of orthopyroxene or cordierite. It is not unlikely that this happened in an evolving intermediate magma chamber that fed the successive injections (Fig. 14a).

(2) The second step corresponds to magma emplacement and the onset of crystallization of 435 quartz, followed by plagioclase, biotite and K-feldspar. It is this step that imprints the textural 436 characteristics of the three units. Decompression and cooling during magma ascent may have 437 led to undercooled melt, resulting in low nucleation and rapid growth of skeletal quartz-1 438 when magma reached its site of emplacement (Fig. 14b). The subsequent evolution has to be 439 discussed for each unit, separately (Fig. 14c, d). 
The first batch of magma (Unit-1) was emplaced in a colder environment. This induced rapid cooling and significant undercooling, which led to high nucleation of quartz followed

442 by limited but to some extent protracted growth resulting in a certain heterogeneity towards

443 larger grain sizes. The crystallization of quartz led in turn to significant supersaturation with

444 respect to plagioclase and biotite. An important peak of nucleation followed by limited

445 growth gave a homogeneous population of small-sized biotite crystals.

446 The next magma injection (Unit-2) intruded Unit-1, i.e. an environment hotter than for the

447 first batch. This led to moderate cooling rate and undercooling, lowered nucleation but

448 increased growth of quartz, with limited Ostwald ripening; the result is a more heterogeneous

449 population of larger quartz grains. The subsequent crystallization of biotite followed the same

450 evolution as quartz, also resulting in a heterogeneous population of larger crystals. The

451 heterogeneity and larger size of both quartz and biotite along with the higher amount of

452 deformation recorded in this unit seem to suggest a longer duration of solidification. Overall,

453 Unit-1 and Unit-2 show crystallization process no so much different from common igneous

454 rocks.

455 The third batch of magma (Unit-3) is distinguished by a more homogeneous population of 456 quartz compared to Unit-2, suggesting that both nucleation and coarsening were to some extent hindered, and therefore that crystallization process has been limited in time. This needs conditions distinct from those operating in the former units, i.e. a process other than cooling rate; this is also supported by the absence of unidirectional growth pattern, thus precluding a

460 significant role of thermal contrast between Unit-2 and Unit-3. The best way to explain these 461 features is to invoke a sudden drop of water pressure by degassing of a magma with higher 462 melt water content, triggering high degree of undercooling by shifting the liquidus of the 463 system, which makes growth and nucleation more rapid. However, this is counteracted by 464 increase in the viscosity of the melt, slowing down diffusion. This may also account for 
465

reducing nucleation of biotite and thus for its high growth rate and dendritic habit. The low diffusivity may also be the cause of biotite crystals forming radiating clusters (nucleation of several grains at a single site).

The end of this step corresponds to the onset of crystallization of K-feldspar (even though it is not possible to determine precisely when this phase started crystallizing), forming mostly a mosaic of equilibrated grains. Note that crystallization of biotite and feldspars maintained in all units the supersaturation of the residual melt in silica and led concomitantly to the crystallization of quartz-2 overgrowing former quartz grains and filling pore spaces.

(3) The last step common to all three units corresponds to the local growth of cordierite $( \pm$ tourmaline); and, finally, to subsolidus fluid-assisted reequilibration (albite, chlorite, etc.).

We are aware that this scenario is very qualitative, but linking it to quantitative assessment of nucleation and growth rates as functions of undercooling is not really possible considering the present state of available experimental studies.

\section{Conclusions}

(1) The studied S-type alkali-feldspar granite was emplaced as three nested units. The crystallization sequence started with garnet, then proceeded with quartz, plagioclase, biotite and K-feldspar, and ended with cordierite. In Unit-1, quartz and biotite are small-sized; in Unit-2, they are coarser-grained forming more a heterogeneous population; and in Unit-3, quartz forms a homogeneous population of smaller grains than in Unit-2, whereas biotite is significantly larger in size (up to $8.5 \mathrm{~cm}$ ).

(2) Quartz occurs mostly as subhedral to euhedral grains, even though more complex shapes are observed. Cathodoluminescence imaging reveals that quartz grains consist of bluish rounded or skeletal core filled and/or surrounded by reddish overgrowth. Biotite is 
poikilitic in all units including mostly quartz grains but also plagioclase and garnet; in unit 3 ,

490 biotite crystals are arranged radially, have dendritic habits and also skeletal cores.

(3) The variability in size and morphology of quartz and biotite is interpreted in terms of variable undercooling related to variable temperature of the host-rocks and to more or less intense degassing due to magma batches characterized by variable melt water content.

(4) Overall, this study illustrates that behind the common "coarse-grained" texture of quartz in granite, subsist primary disequilibrium crystallization textures. This probably results from a favourable situation in which the thermal evolution has not totally erased the initial crystallisation textures. However, it is not impossible that majority of granites kept relics that will not be visible without examination under cathodoluminescence. Finally, the claim of Welsch et al. (2013) that all euhedral olivine crystals in basaltic rocks are initially dendritic or 500 skeletal could also be applicable to other minerals and rock types.

\section{Acknowledgements}

This work was supported by the TelluS Program of CNRS/INSU. We thank the Centre Terrae

504 Genesis for assistance in field work and sample polishing, Alexandre Flammang for thin

505 section preparation, Emmanuel Davy for zircon separation, and Olivier Rouer for assistance 506 with electron microprobe analyses. We are indebted to M. Holness, D. London and O.

507 Müntener for their helpful comments on an earlier version of this paper. Constructive reviews 508 by J. Hammer and J. Vander Auwera are gratefully acknowledged.

\section{$510 \quad$ References}

511 Ackerson, M.R., Mysen, B.O., Tailby, N.D., Watson, E.B., 2018. Low-temperature

512 crystallization of granites and the implications for crustal magmatism. Nature 513 doi.org/10.1038/s41586-018-0264-2. 
514 Ahmed, S.A.E., 2011. The origin of quartz glomerocrysts: insights from the rhyolite dike at

$515 \quad$ Medicine Park, Oklahoma. Masters Theses, 56p.

516 http://scholarsmine.mst.edu/masters_theses/5032.

517 Almeev, R.R., Holtz, F., Koepke, J., Parat, F., Botcharnikov, R.E., 2007. The effect of $\mathrm{H}_{2} \mathrm{O}$

518 on olivine crystallization in MORB: Experimental calibration at $200 \mathrm{MPa}$. American

$519 \quad$ Mineralogist 92, 670-674.

520 Ballouard, C., Poujol, M., Boulvais, P., Branquet, Y., Tartèse, R., Vigneresse, J.L., 2016. Nb-

521 Ta fractionation in peraluminous granites: A marker of the magmatic-hydrothermal 522 transition. Geology 44, 231-234.

523 Barbey P., Marignac C., Montel J.M., Macaudière J., Gasquet D., Jabbori J., 1999. Cordierite 524 growth textures and the conditions of genesis and emplacement of crustal granitic magmas: 525 the Velay granite complex (Massif Central, France). Journal of Petrology 40(9), 14255261441.

527 Bau, M., 1996. Controls on the fractionation of isovalent trace elements in magmatic and 528 aqueous systems: evidence from $\mathrm{Y} / \mathrm{Ho}, \mathrm{Zr} / \mathrm{Hf}$, and lanthanide tetrad effect. Contributions 529 to Mineralogy and Petrology 123, 323-333.

530 Cabane, H., Laporte, D., Provost, A., 2001. Experimental investigation of the kinetics of 531 Ostwald ripening of quartz in silicic melts. Contributions to Mineralogy and Petrology 142, $532 \quad 361-373$.

533 Cashman, K.V., Marsh, B.D., 1988. Crystal size distribution (CSD) in rocks and the kinetics 534 and dynamics of crystallization II: Makaopuhi lava lake. Contributions to Mineralogy and 535 Petrology 99(3), 292-305.

536 Cawthorn, R.G., 1996. Layered intrusions. Elsevier, Amsterdam, 531p. 
537 Clemens, J.D., Birch, W.D., 2012. Assembly of a zoned volcanic magma chamber from

538 multiple magma batches: The Cerberean Cauldron, Marysville Igneous Complex, $539 \quad$ Australia. Lithos 155: 272-288.

540 Decitre, S., Gasquet, D., Marignac, C., 2002. Genesis of orbicular granitic rocks from the 541 Ploumanac'h Plutonic Complex (Brittany, France). European Journal of Mineralogy 14, $542 \quad 715-731$.

543 Donaldson, C.H., 1974. Olivine crystal types in harrisitic rocks of the Rhum pluton and in $544 \quad$ Archean spinifex rocks. Geological Society of America Bulletin 85, 1721-1726.

545 Donaldson, C.H., 1976. An experimental investigation of olivine morphology. Contributions $546 \quad$ to Mineralogy and Petrology 57(2), 187-213.

547 Donaldson, C.H.,1982. Spinifex-textured komatiites: a review of textures, compositions and 548 layering. In: Arndt, N.T., Nisbet, E.G. (Eds) Komatiites. Allen and Unwin, London, pp. $549 \quad 213-244$.

550 Donaldson, C.H., Henderson, C.M.B., 1982. Interpretation of round embayment in quartz $551 \quad$ crystals. Mineralogical Magazine 52, 27-33.

552 El Bouseily, A.M., El Sokkary, A.A., 1975. The relation between Rb, Ba and Sr in granitic 553 rocks. Chemical Geology 16, 207-219.

554 Evensen, N.M., Hamilton, M.J., O'Nions, R.J., 1978. Rare-earth abundances in chondritic 555 meteorites. Geochimica et Cosmochimica Acta 42, 1199-1212.

556 Faure, F., Arndt, N., Libourel, G., 2006. Formation of spinifex texture in komatiites: an 557 experimental study. Journal of Petrology 47, 1591-1610.

558 Faure, F., Trolliard, G., Nicollet, C., Montel, J. M., 2003. A developmental model of olivine 559 morphology as a function of the cooling rate and the degree of undercooling. Contributions $560 \quad$ to Mineralogy and Petrology 145, 251-263. 
561 Fluck, P., Piqué, A., Schneider, J.L., Whitechurch, H., 1991. Le socle vosgien. Science

562 Géologique Bulletin 44, 207-235.

563 Frindt, S., Haapala, I., 2004. Anorogenic Gross Spitzkoppe granite stock in central western

564 Namibia: Part II. Structures and textures indicating crystallization from undercooled melt. $565 \quad$ American Mineralogist 89, 857-866.

566 Frost, B.R., Barnes, C.G., Collins, W.J., Arculus, R.J., Ellis, D.J., Frost, C.D., 2001. A 567 geochemical classification for granitic rocks. Journal of Petrology 42, 2033-2048.

568 Gillespie, M.R., Styles, M.T., 1999. BGS Rock Classification Scheme. Volume 1:

569 Classification of igneous rocks. British Geological Survey Research Report (2nd edition) 570 RR 99-06, 52p.

571 Götze, J., Plötze, M., Habermann, D., 2001. Origin, spectral characteristics and practical 572 applications of the cathodoluminescence (CL) of quartz- $\alpha$ review. Mineralogy and $573 \quad$ Petrology 71(3-4), 225-250.

574 Haapala, I., Lukkari, S., 2005. Petrological and geochemical evolution of the Kymi stock, a 575 topaz granite cupola within the Wiborg rapakivi batholith, Finland. Lithos 80, 347-362. 576 Higgins, M.D., 2011. Textural coarsening in igneous rocks. International Geology Review $577 \quad 53(3-4), 354-376$.

578 Holness, M.B., 2005. Spatial constraints on magma chamber replenishment events from 579 textural observations of cumulates: The Rum Layered Intrusion, Scotland. Journal of $580 \quad$ Petrology 46(8), 1585-1601.

581 Holness, M. B., Anderson, A. T., Martin, V. M., MacLennan, J., Passmore, E., Schwindinger, 582 K., 2007a. Textures in partially solidified crystalline nodules: a window into the pore 583 structure of slowly cooled mafic intrusions. Journal of Petrology 48(7), 1243-1264. 
Holness, M.B., Nielsen, T.F.D., Tegner, C., 2007b. Textural maturity of cumulates: A record of chamber filling, liquidus assemblage, cooling rate and large-scale convection in mafic layered intrusions. Journal of Petrology 48(1), 141-157.

Holness, M.B., Tegner, C., Nielsen, T.F.D., Stripp, G., Morse, S.A., 2007c. A textural record of solidification and cooling in the Skaergaard Intrusion, East Greenland. Journal of Petrology 48(12), 2359-2377.

Irber, W., 1999. The lanthanide tetrad effect and its correlation with $\mathrm{K} / \mathrm{Rb}, \mathrm{Eu} / \mathrm{Eu}$ * $\mathrm{Sr} / \mathrm{Eu}$, Y/Ho, and $\mathrm{Zr} / \mathrm{Hf}$ of evolving peraluminous granite suites. Geochimica et Cosmochimica Acta 63, 489-508.

\section{3}

Ivanov, I.M., Grozdanov, L.A., 2001. Biotite in the granitic pegmatites in the deposit of Smilovene, Koprivshtitsa region. Comptes Rendus de l'Académie bulgare des Sciences 54(4), 59-64.

Johannes, W., Holtz, F., 1996. Petrogenesis and Experimental Petrology of Granitic Rocks. Springer-Verlag, Berlin, Heidelberg. 335 pp.

Jahn, B.M., Wu, F., Capdevila, R., Martineau, F., Zhao, Z., Wang, Y., 2001. Highly evolved juvenile granites with tetrad REE patterns: the Woduhe and Baerzhe granites from the Great Xing'an Mountains in NE China. Lithos 59, 171-198.

601 mountains (north-eastern France): implications for the metamorphic history of high-grade rocks during the Variscan orogeny. Tectonophysics 205, 387-407.

Lesher, C.E., Walker, D., 1988. Cumulate maturation and melt migration in a temperature gradient. Journal of Geophysical Research, Solid Earth 93, 10295-10311. protoplanetary disk gas. Science Advances 4(7), eaar3321. 
Lofgren, G., 1974. An experimental study of plagioclase crystal morphology. American Journal of Science 274, 243-273.

Lofgren, G., 1980. Experimental studies on the dynamic crystallization of silicate melts. In: Hargraves, R.B. (Ed.) Physics of magmatic processes, Princeton University Press, New Jersey, pp. 487-551.

Lofgren, G.E., Donaldson, C.H., 1975. Curved branching crystals and differentiation in comblayered rocks. Contributions to Mineralogy and Petrology 49, 309-319.

London, D., 2005. Granitic pegmatites: an assessment of current concepts and directions for the future. Lithos 80, 281-303.

London, D., 2009. The origin of primary textures in granitic pegmatites. Canadian Mineralogist 47(4), 697-724.

London, D., Morgan, G.B., 2017. Experimental crystallization of the Macusani obsidian, with applications to lithium-rich granitic pegmatites. Journal of Petrology 58(5), 1005-1030.

MacLellan, H.E., Trembath, L.T., 1991. The role of quartz crystallization in the development and preservation of igneous texture in granitic rocks; experimental evidence at $1 \mathrm{kbar}$. American Mineralogist 76, 1291-1305.

Marsh, B.D., 1988. Crystal size distribution (CSD) in rocks and the kinetics and dynamics of crystallization. I. Theory. Contributions to Mineralogy and Petrology 99, 277-291.

Médard, E., Grove, T.L., 2008. The effect of $\mathrm{H}_{2} \mathrm{O}$ on the olivine liquidus of basaltic melts: Experiments and thermodynamic models. Contributions to Mineralogy and Petrology 155, 417-432.

Milman-Barris, M.S., Beckett, J.R., Baker, M.B., Hofman, A.E., Morgan, Z., Crowley, M.R., Vielzeuf, D., Stolper, E., 2008. Zoning of phosphorus in igneous olivine. Contributions to Mineralogy and Petrology 155, 739-765. 
632 Müller, A., Kronz, A., Breiter, K., 2002. Trace elements and growth patterns in quartz: a

633 fingerprint of the evolution of the subvolcanic Podlesí Granite System (Krusné hory Mts.,

634 Czech Republic). Bulletin of the Czech Geological Survey 77(2), 135-145.

635 Rey, P., Burg, J. P., Lardeaux, J.M., Fluck, P., 1989. Evolutions métamorphiques contrastées

636 dans les Vosges orientales : témoins d'un charriage dans la chaîne varisque. Comptes

637 Rendus de l'Académie des sciences, Paris, Série 2, 309, 815-821.

638 Scaillet, B., Pichavant, M., Roux, J., 1995. Experimental crystallization of leucogranite 639 magmas. Journal of Petrology 36, 663-705.

640 Seitz, S., Putlitz, B., Baumgartner, L.P., Escrig, S., Meibom, A., Bouvier, A.S., 2016. Short 641 magmatic residence times of quartz phenocrysts in Patagonian rhyolites associated with 642 Gondwana breakup. Geology 44, 67-70.

643 Shannon, J.R., Walker, B.M., Carten, R.B., Geraghty, E.P., 1982. Unidirectional solidification 644 textures and their significance in determining relative ages of intrusions at the Henderson 645 Mine, Colorado. Geology 10, 293-297.

646 Skrzypek, E., Schulmann, K., Tabaud, A.S., Edel, J.B., 2014. Palaeozoic evolution of the 647 Variscan Vosges mountains. In: Schulmann, K., Martìnez Catalán, J.R., Lardeaux, J.M., 648 Janoušek, V., Oggiano, G. (Eds), The Variscan Orogeny: Extent, Timescale and the 649 Formation of the European Crust. Geological Society, London, Special Publications 405, $650 \quad 45-75$.

651 Smillie, R.W., Turnbull, R.E., 2014. Field and petrographical insight into the formation of 652 orbicular granitoids from the Bonney Pluton, southern Victoria Land, Antarctica.

653 Geological Magazine 151, 534-549.

654 Streckeisen, A., Le Maitre, R.W., 1979. A chemical approximation to the modal QAPF 655 classification of the igneous rocks. Neues Jahrbuch für Mineralogie, Abhandlungen 136, $656 \quad 169-206$. 
657 Sun, S.-S., McDonough, W.F., 1989. Chemical and isotopic systematics of oceanic basalts:

658 implications for mantle composition and processes. In: Saunders, A.D., Norry, M.J. (Eds),

659 Magmatism in the Ocean Basins. Geological Society, London, Special Publications 42,

$660 \quad 313-345$.

661 Swanson, S. E., 1977. Relation of nucleation and crystal-growth rate to the development of 662 granitic textures. American Mineralogist 62, 966-978.

663 Swanson, S.E., Fenn, P.M., 1986. Quartz crystallization in igneous rocks. American $664 \quad$ Mineralogist 71, 331-342.

665 Tabaud, A. S., Janoušek, V., Skrzypek, E., Schulmann, K., Rossi, P., Whitechurch, H., Guerrot, 666 C. \& Paquette, J. L., 2015. Chronology, petrogenesis and heat sources for successive 667 Carboniferous magmatic events in the Southern-Central Variscan Vosges Mts (NE France). 668 Journal of the Geological Society 172, 87-102.

669 Vernon, R.H. 1985. Possible role of superheated magma in the formation of orbicular 670 granitoids. Geology 13, 843-845.

671 Watson, E.B., Harrison, T.M., 1983. Zircon saturation revisited: temperature and composition 672 effects in a variety of crustal magma types. Earth and Planetary Science Letters 64, 295$673 \quad 304$.

674 Watt, G.R., Wright, P., Galloway, S., McLean, C., 1997. Cathodoluminescence and trace 675 element zoning in quartz phenocrysts and xenocrysts. Geochimica et Cosmochimica Acta, $676 \quad 61,4337-4348$.

677 Welsch, B., Faure, F., Famin, V., Baronnet, A., Bachèlery, P., 2013. Dendritic crystallization: 678 A single process for all the textures of olivine in basalts? Journal of Petrology 54, 539-574.

679 Welsch, B., Hammer, J., Hellebrand, E., 2014. Phosphorus zoning reveals dendritic $680 \quad$ architecture of olivine. Geology, 42(10), 867-870. 
681 Whalen, J.B., Currie, K.L., Chappell, B.W., 1987. A-type granites: geochemical

682 characteristics, discrimination and petrogenesis. Contributions to Mineralogy and

683 Petrology 95, 407-419.

684 Xing, C.M., Wang, C.Y., Tan, W., 2017. Disequilibrium growth of olivine in mafic magmas

685 revealed by phosphorus zoning patterns of olivine from mafic-ultramafic intrusions. Earth

686 and Planetary Science Letters, 479, 108-119.

687

688

Figure captions

689

690 Fig. 1. Cross-section of the alkali-feldspar granite body, with sample location. Sample

691 numbers refer to whole-rock and mineral analyses of Table 1 and Supplementary material

692 SM.3.

693

694 Fig. 2. Unit-1. Size and morphology of biotite and quartzofeldspathic matrix. (a) Polished

695 slab; (b) and (c) thin sections in plane polarized light and crossed nicols, respectively. $\left(\mathrm{S}_{\mathrm{m}}=\right.$

696 magmatic fabric; $\mathrm{qz}=$ quartz; fsp = feldspar; Kfs = K-feldspar; $\mathrm{pl}=$ plagioclase; $\mathrm{bt}=$ biotite;

697 grt = garnet.)

698

699 Fig. 3. Unit-2. (a) Polished slab showing the size of biotite and its rough orientation along the

700 syn-magmatic foliation $\left(\mathrm{S}_{\mathrm{m}}\right)$. (b) Detail of biotite (blades) and garnet (dots) in a weakly

701 foliated part of the unit (rough surface). (c) Polished slab showing an autolithic enclave

702 wrapped by the foliation; note also the larger grain size of the lower part of the slab. (d) Thin section in plane polarized light showing the size and morphology of biotite, and texture of the quartzofeldspathic matrix. 
Fig. 4. Unit-3. (a) and (b) Polished blocs showing the 3D organization of biotite plates. (c)

707 Polished slab showing the disposition of biotite and small rounded garnet grains. (c) Thin section in plane polarized light showing the size and morphology of biotite and quartz.

Fig. 5. (a) Multi-element plot normalized to Primitive Mantle (Sun and McDonough, 1989).

(b) REE patterns normalized to chondrite (Evensen et al., 1978).

712

Fig. 6. Optical microphotographs of quartz. (a) Quartz grain with serrated edges. (b)

714 Equilibrated grain boundaries between quartz grains (see also Fig.7e). (c) Quartz film

715 (arrowed) along grain boundaries, in crystallographic continuity with the rounded quartz

716 grain. (d) Triangular extensions (arrowed) of quartz along feldspar-feldspar or feldspar-quartz

717 grain boundaries. (e) Re-entrants with tips (arrowed) tending to meet and form an inclusion.

718 (f) Interstitial quartz (arrowed) along grain boundaries between feldspar grains. (b), (c), (d)

719 and (e): Unit-3; (a) and (f): Unit-2.

720

721 Fig. 7. Cathodoluminescence images of quartz. (a) Elliptical cores (qz-1) with wavy or jagged

722 outlines, overgrown and welded by a second generation of quartz (qz-2); note the hollow core

723 of qz-1 to the right. (b) and (c) Cores showing branching arms. (d) Hollow crystal with roughly radiating branches. (e) Coalescence of quartz grains welded by reddish quartz overgrowth leading to an equilibrated grain assemblage. (f) Symplectitic quartz intergrowth

726 with biotite (arrowed); note that the symplectitic quartz overgrows a bluish quartz grain.

727 Other mineral phases are K-feldspar (blue and green), plagioclase (light brown), albite

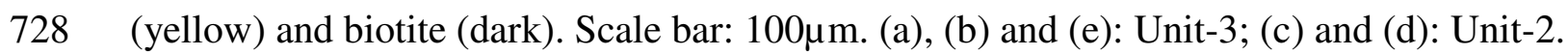


Fig. 8. Size distribution of whole quartz grains in the three units. Note the greater size heterogeneity in Unit-2. (aver. = average and standard deviation; $n=$ number of grains measured; diam. $=$ diameter.)

Fig. 9. Microphotographs of garnet. (a) Euhedral garnet crystal (Unit-3). (b) Rounded garnet grain included in plagioclase (Unit-2). (c) Retrogressed garnet crystal embedded in a biotiteplagioclase groundmass (Unit-2).

Fig. 10. Mineral compositions: (a) Garnet in the Almandine-Pyrope-Spessartite+Grossularite triangle; (b) Biotite in the $\mathrm{Al}^{\mathrm{VI}}$ vs. $(\mathrm{Fe}+\mathrm{Mg}$ ) diagram; and (c) Feldspars in the $\mathrm{Ab}-\mathrm{Or}-\mathrm{An}$ triangle $(\mathrm{p}=$ perthite $)$. Compositions presented in these diagrams are given in the Supplementary material SM.3.

Fig. 11. Morphology of biotite. (a) Strongly poikilitic aspect of biotite including numerous quartz grains (Unit-3). (b) Branching, bifid, biotite crystal from Unit-2. (c) and (d) Dendritic crystals from Unit-3. (e) Biotite showing hollow core (Unit-2). (f) Biotite with hollow core filled with feldspar mainly (Unit-3).

Fig.12. Size distribution of biotite crystals in the three units (aver. = average and standard deviation; $\mathrm{n}=$ number of grains measured; diam. = diameter).

Fig. 13. Morphology of feldspars. (a) Back-scattered electron microscopy (BSEM) image showing a K-feldspar groundmass containing euhedral plagioclase crystals and rounded quartz grains; note the presence of albite veinlets along K-feldspar grain boundaries and around the euhedral plagioclase crystal. (b) BSEM image of glomerophyric texture of 
755 plagioclase in a groundmass consisting of quartz (dark grey) and K-feldspar (light grey). (c)

756 Optical microscopy image of plagioclase crystal showing a partly retrogressed core rimmed

757 by albite and K-feldspar. (d) CL image showing the matrix forming euhedral to subhedral K-

758 feldspar crystals (green to grey). (e) Optical microscopy image of a perthitic K-feldspar

759 crystal. (f) CL image showing partial replacement of plagioclase crystals into albite or

760 plagioclase rimmed with K-feldspar and albite (same grain as in c). (a), (b), (c), (e) and (f):

761 Unit-3; (d): Unit-2.

762

763 Fig. 14. Interpretative sketch illustrating the main step of solidification of the alkali-feldspar

764 granite $($ melt $=$ light pink, garnet $=$ red, quartz- $1=$ grey, quartz- $2=$ light grey, plagioclase $=$

765 brown, biotite = black, primary K-feldspar = green, secondary albite $=$ yellow, secondary K-

766 feldspar = blue). 

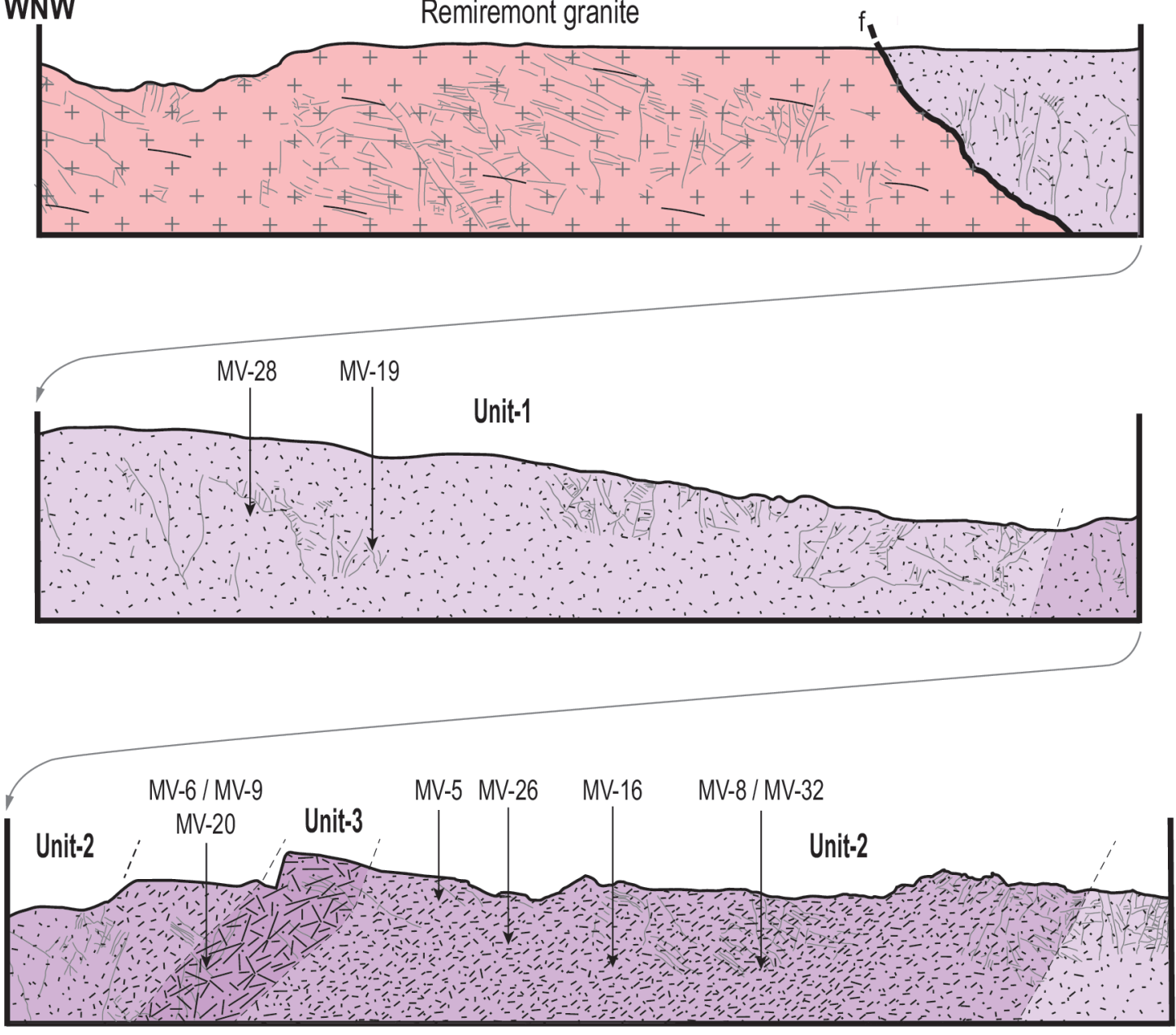

Unit-1

$+\backslash+$ Remiremont granite

1. Akfs granite - Unit-3

Akfs granite - Unit-2 $\therefore \because$ Akfs granite - Unit-1

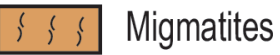

Fractures

Fault 


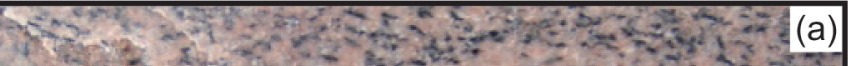

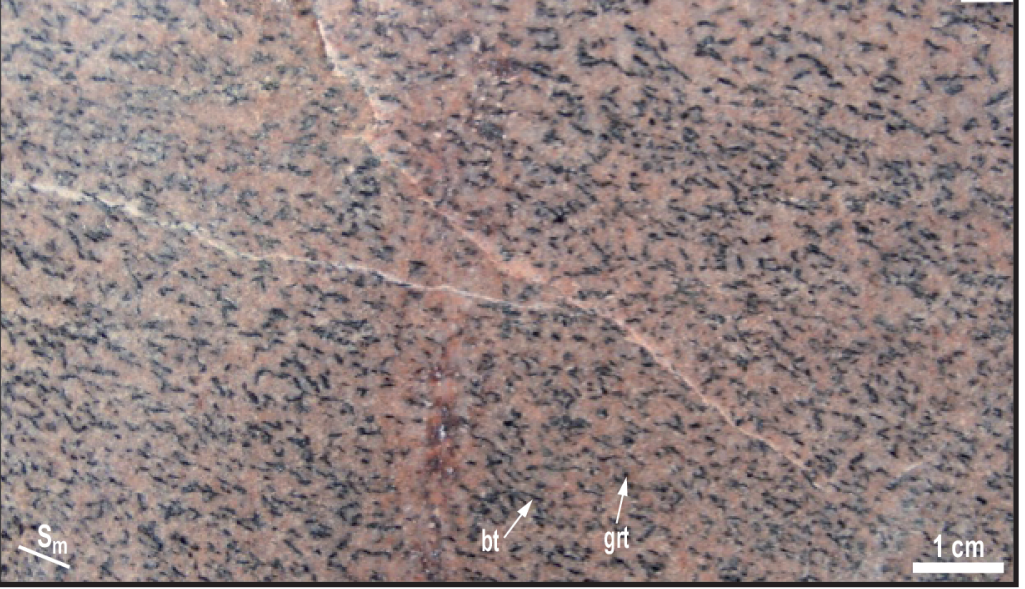

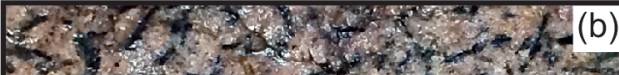

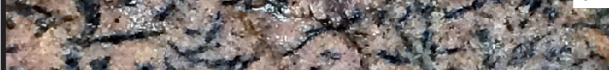

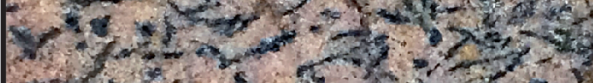

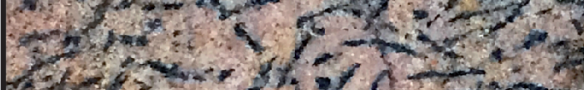

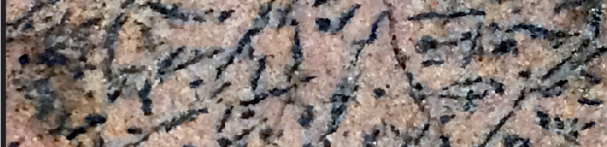
$7 x-3 ; y^{2}=2 x$

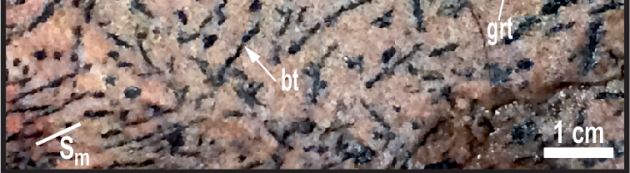
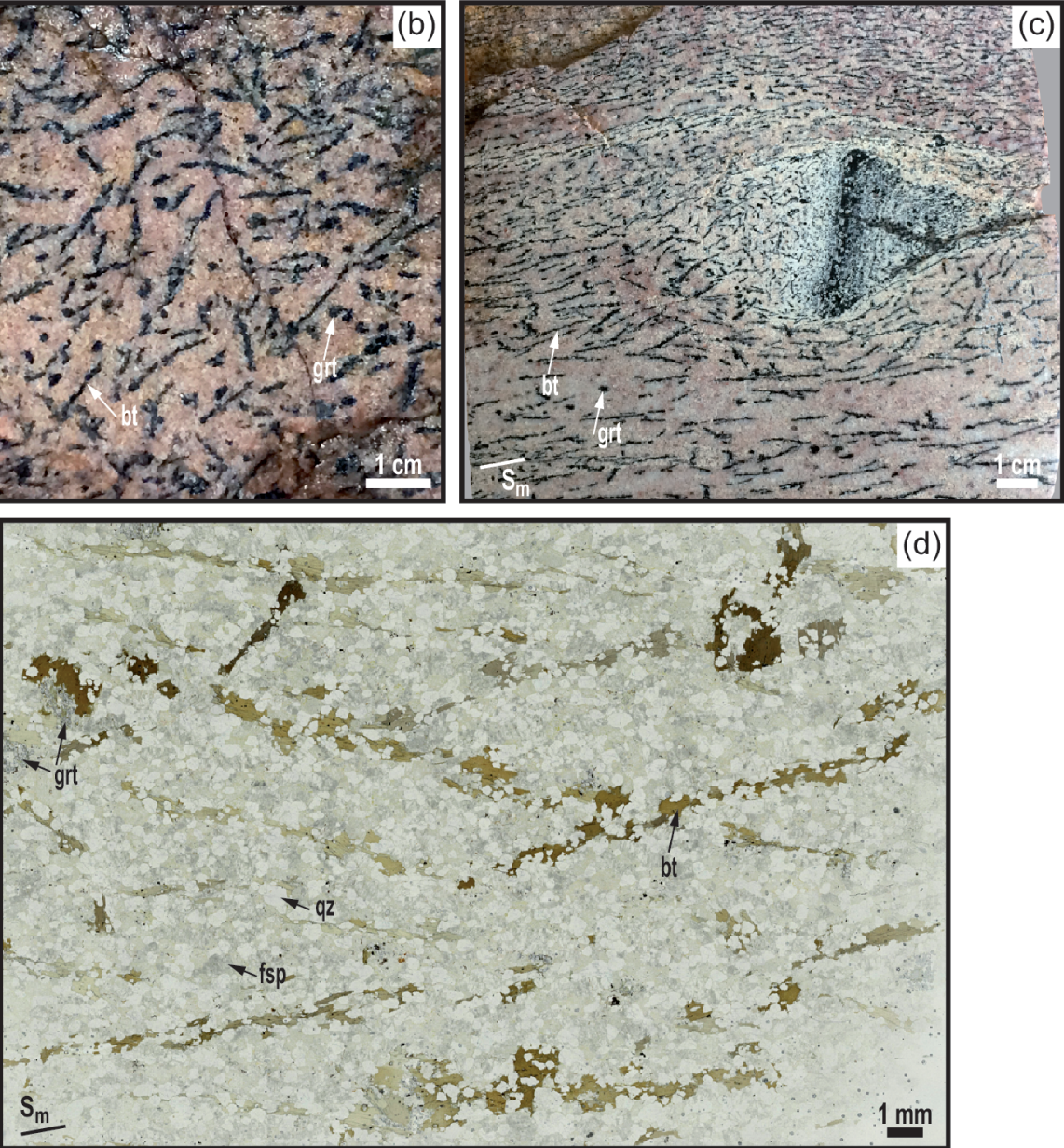


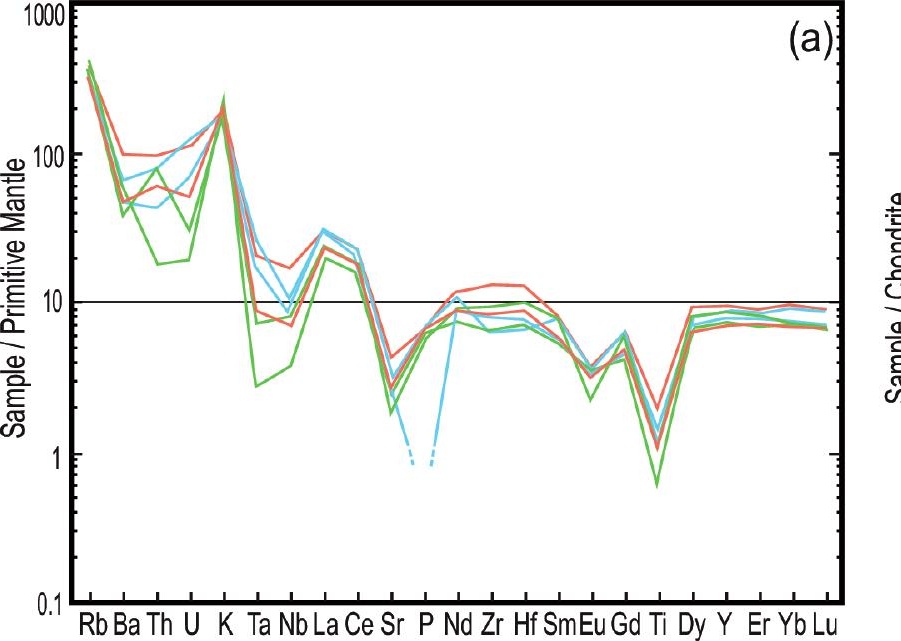

(b)

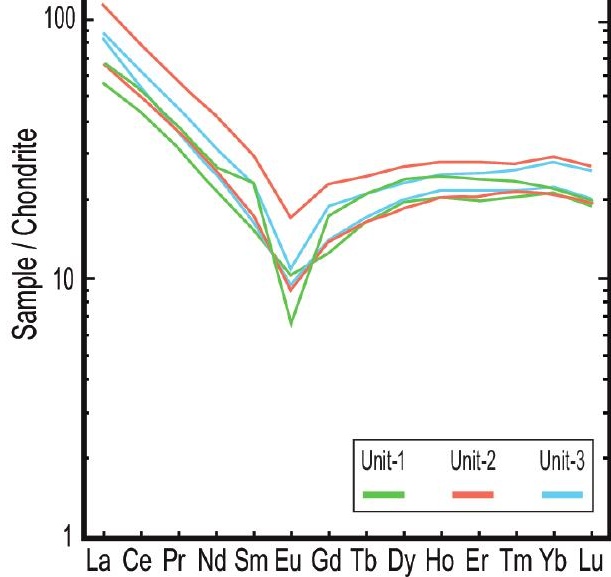




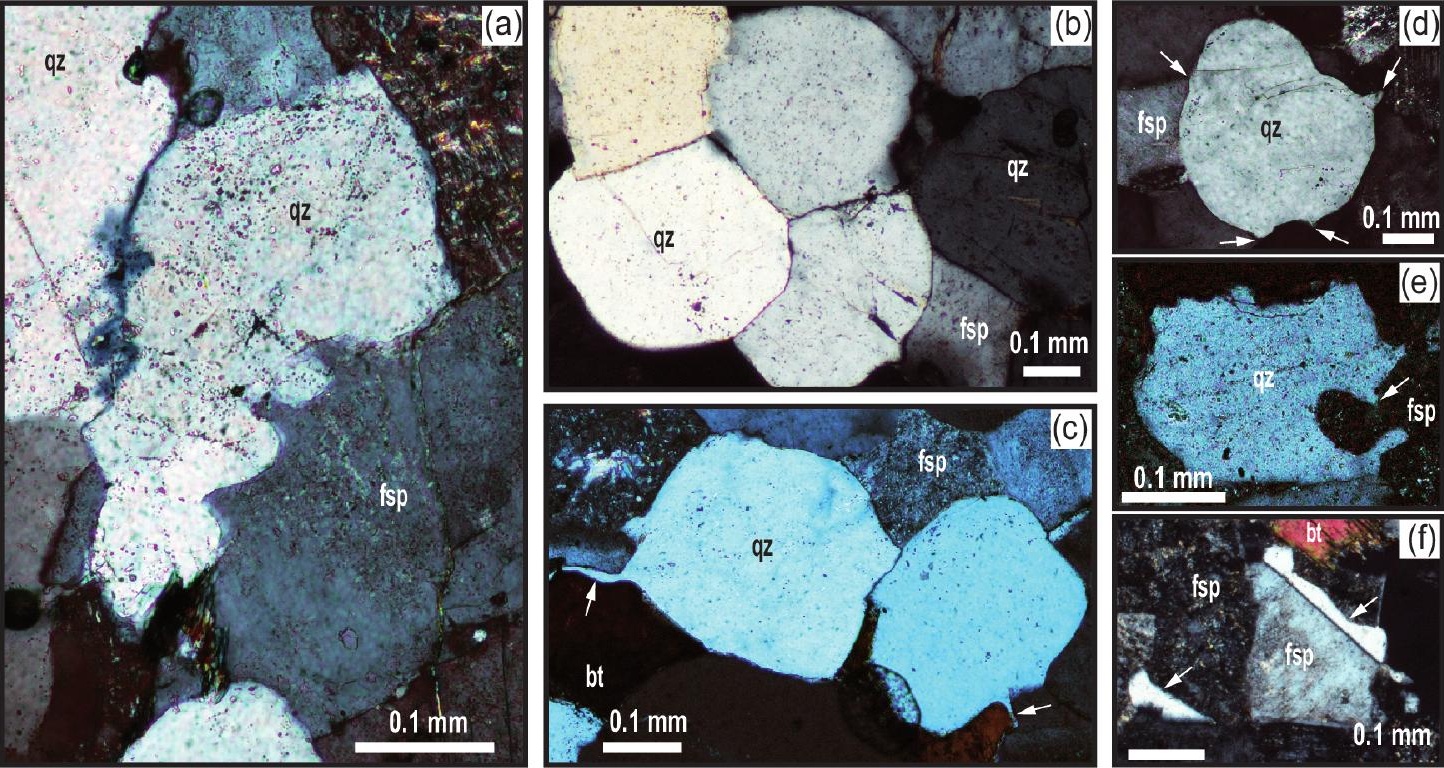




\section{Unit-1}
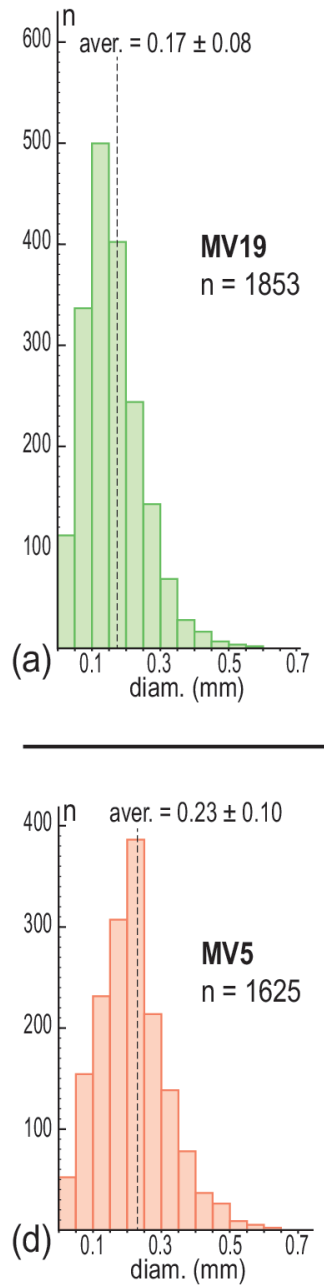

Unit-3
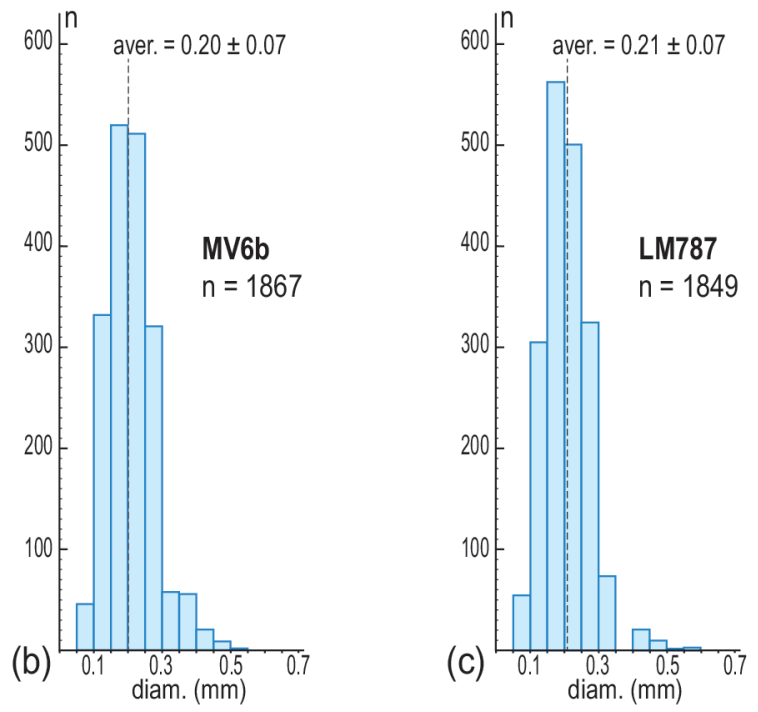

Unit-2
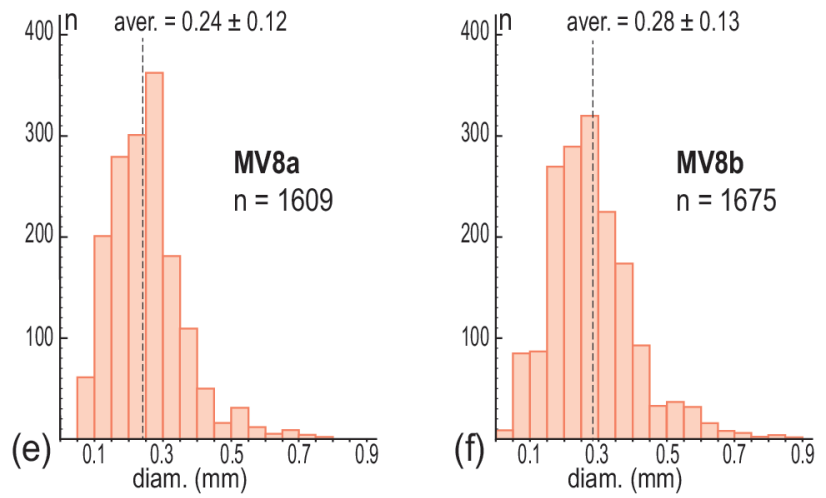


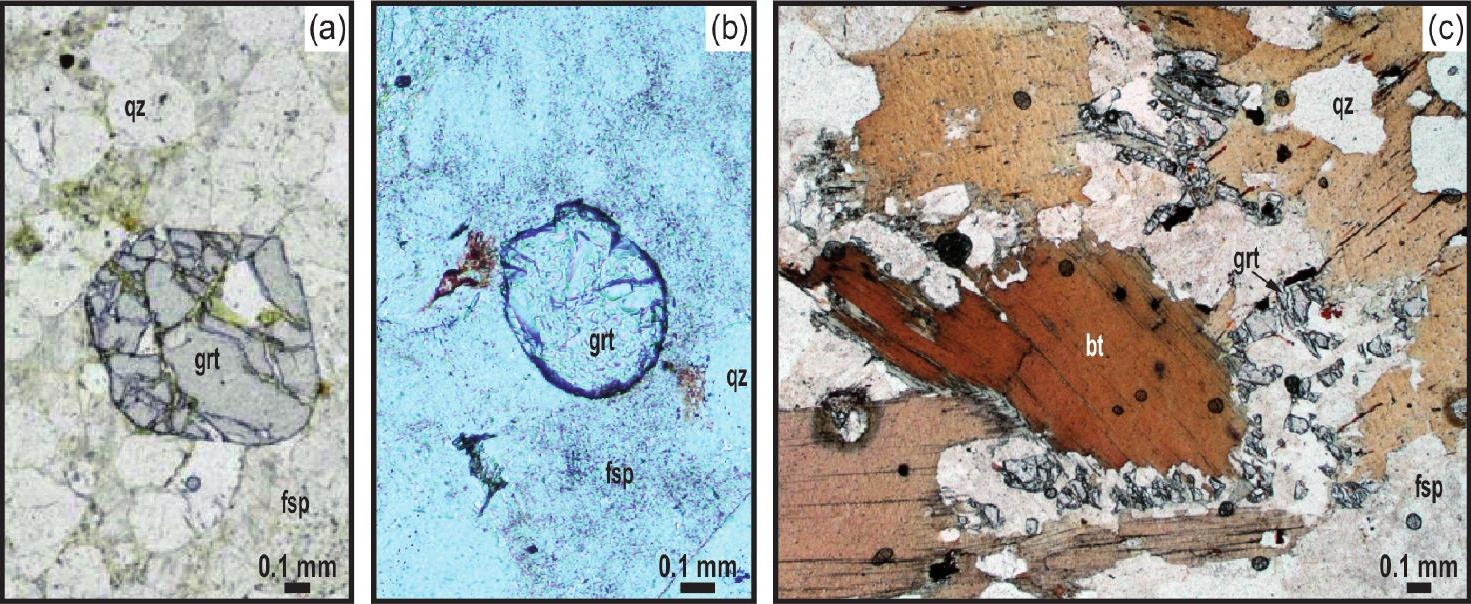




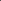

- forthor

(f) 


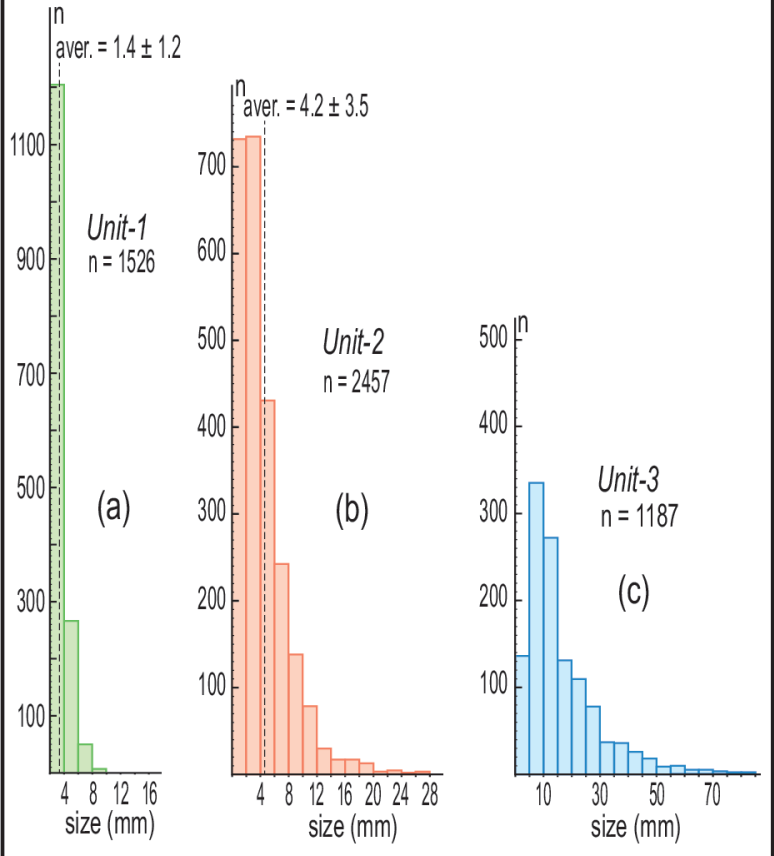




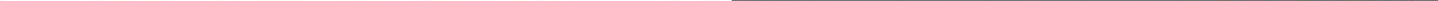




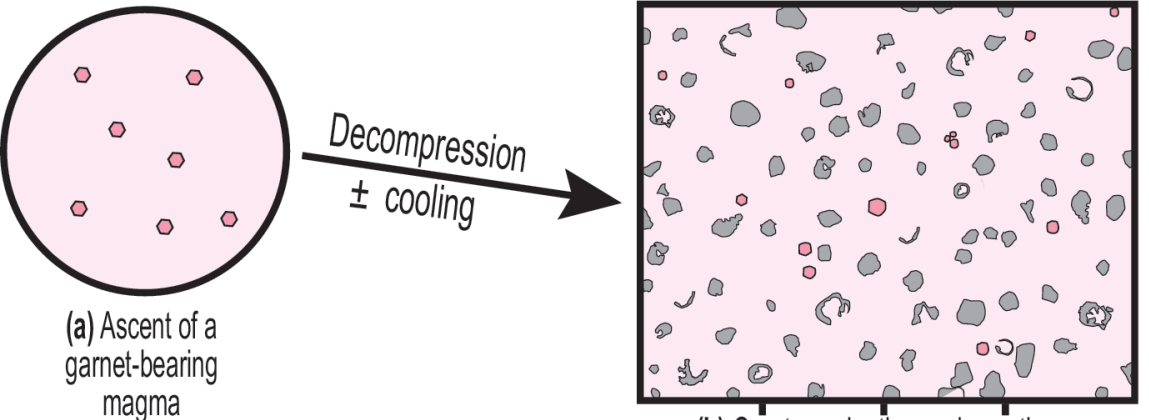

magma

(b) Quartz nucleation and growth

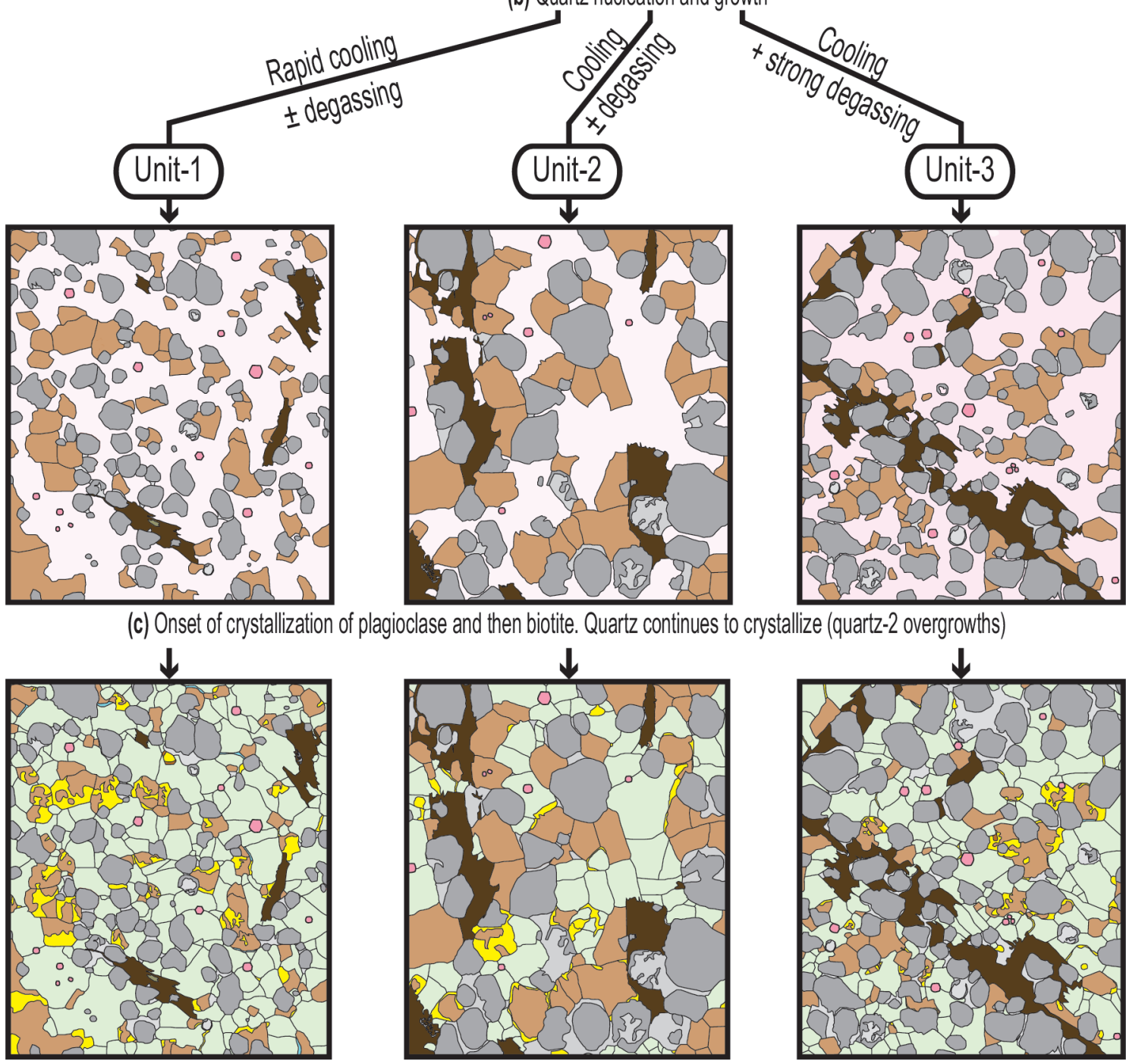

(d) Onset of K-feldspar crystallization. Quartz continues to crystallize, filling residual pore spaces. Late crystallization of cordierite (not shown), followed by subsolidus fluid-assisted alteration (albite, chlorite, etc.) 
Table 1: Whole-rock major (wt.\%) and trace element $(\mu \mathrm{g} / \mathrm{g}$ ) composition of the three units of the alkali-feldspar granite. Shown for comparison: whole-rock major element composition of Himalayan leucogranite (HL; Scaillet et al., 1995) and Rubicon ignimbrite (RI; Clemens et al., 2012).

\begin{tabular}{|c|c|c|c|c|c|c|c|c|}
\hline Unit & Unit-1 & & Unit-2 & & Unit-3 & & HL & RI \\
\hline Sample & MV19 & MV28 & MV8 & MV16 & MV9 & MV20 & DK89 & 9397 \\
\hline $\mathrm{SiO}_{2}$ & 74.18 & 74.03 & 69.70 & 74.10 & 72.86 & 75.22 & 73.04 & 75.77 \\
\hline $\mathrm{Al}_{2} \mathrm{O}_{3}$ & 14.19 & 12.70 & 14.09 & 13.01 & 13.70 & 13.04 & 15.32 & 13.54 \\
\hline $\mathrm{FeO}^{\text {tot }}$ & 1.10 & 1.89 & 3.53 & 1.87 & 2.41 & 1.56 & 0.74 & 1.69 \\
\hline $\mathrm{MnO}$ & - & 0.03 & 0.06 & 0.03 & 0.04 & 0.02 & 0.01 & 0.01 \\
\hline $\mathrm{MgO}$ & 0.32 & 0.52 & 1.30 & 0.60 & 0.94 & 0.57 & 0.20 & 0.31 \\
\hline $\mathrm{CaO}$ & 0.24 & 0.21 & 0.36 & 0.30 & 0.36 & 0.29 & 0.85 & 0.65 \\
\hline $\mathrm{Na}_{2} \mathrm{O}$ & 2.24 & 1.88 & 2.02 & 2.23 & 2.61 & 2.59 & 3.85 & 2.64 \\
\hline $\mathrm{K}_{2} \mathrm{O}$ & 7.08 & 5.97 & 6.02 & 6.27 & 5.31 & 5.40 & 4.96 & 5.27 \\
\hline $\mathrm{TiO}_{2}$ & 0.13 & 0.23 & 0.44 & 0.24 & 0.29 & 0.23 & 0.13 & 0.11 \\
\hline $\mathrm{P}_{2} \mathrm{O}_{5}$ & 0.15 & 0.12 & 0.14 & 0.14 & - & 0.15 & 0.14 & \\
\hline LOI & 1.29 & 1.23 & 1.32 & 1.04 & 1.48 & 1.34 & 0.79 & \\
\hline Total & 100.93 & 98.80 & 98.97 & 99.82 & 100.00 & 100.40 & 100.03 & 100.00 \\
\hline As & 3.7 & 3.1 & 4.0 & 3.0 & 9.4 & 7.2 & & \\
\hline $\mathrm{Ba}$ & 429 & 255 & 689 & 333 & 331 & 448 & & \\
\hline $\mathrm{Be}$ & 0.7 & 0.9 & 1.0 & 0.9 & 1.0 & 1.2 & & \\
\hline $\mathrm{Co}$ & 1.6 & 2.2 & 7.2 & 3.0 & 4.7 & 3.1 & & \\
\hline $\mathrm{Cr}$ & 4.8 & 12 & 40 & 13 & 25 & 18 & & \\
\hline Cs & 8.8 & 7.2 & 12.7 & 9.4 & 11.9 & 9.4 & & \\
\hline $\mathrm{Cu}$ & 4.3 & 2.7 & 11.5 & 7.1 & 7.4 & 6.7 & & \\
\hline $\mathrm{Ga}$ & 17 & 16 & 18 & 16 & 17 & 16 & & \\
\hline $\mathrm{Ge}$ & 1.2 & 1.2 & 1.5 & 1.2 & 1.4 & 1.4 & & \\
\hline Hf & 2.3 & 3.1 & 4.1 & 2.8 & 2.5 & 2.1 & & \\
\hline $\mathrm{Nb}$ & 2.7 & 5.8 & 12 & 5.1 & 7.4 & 6.0 & & \\
\hline $\mathrm{Ni}$ & 43 & 4.6 & 80 & 6.9 & 60 & 33 & & \\
\hline $\mathrm{Pb}$ & 11 & 11 & 17 & 23 & 14 & 14 & & \\
\hline $\mathrm{Rb}$ & 264 & 234 & 236 & 205 & 222 & 211 & & \\
\hline $\mathrm{Sc}$ & 2.3 & 0.1 & 12 & 0.1 & 7.2 & 4.9 & & \\
\hline $\mathrm{Sn}$ & 2.4 & 1.8 & 3.6 & 2.7 & 6.3 & 5.6 & & \\
\hline $\mathrm{Sr}$ & 51 & 38 & 91 & 56 & 61 & 64 & & \\
\hline $\mathrm{Ta}$ & 0.1 & 0.3 & 0.9 & 0.4 & 1.1 & 0.7 & & \\
\hline Th & 1.6 & 6.9 & 8.5 & 5.1 & 3.7 & 6.7 & & \\
\hline $\mathrm{U}$ & 0.4 & 0.6 & 2.4 & 1.1 & 1.5 & 2.7 & & \\
\hline $\mathrm{V}$ & 4.8 & 13 & 49 & 16 & 29 & 21 & & \\
\hline W & - & - & 1.1 & - & 1.5 & 1.5 & & \\
\hline $\mathrm{Y}$ & 33 & 39 & 44 & 32 & 36 & 39 & & \\
\hline $\mathrm{Zn}$ & 16 & 25 & 55 & 27 & 33 & 28 & & \\
\hline $\mathrm{Zr}$ & 75 & 106 & 149 & 96 & 93 & 72 & & \\
\hline $\mathrm{La}$ & 14.02 & 16.74 & 27.55 & 16.57 & 20.65 & 21.50 & & \\
\hline $\mathrm{Ce}$ & 28.36 & 34.07 & 50.95 & 32.16 & 35.57 & 40.86 & & \\
\hline $\operatorname{Pr}$ & 3.06 & 3.65 & 5.66 & 3.53 & 3.58 & 4.38 & & \\
\hline $\mathrm{Nd}$ & 10.34 & 12.83 & 20.10 & 12.36 & 12.12 & 15.05 & & \\
\hline $\mathrm{Sm}$ & 2.36 & 3.57 & 4.59 & 2.65 & 2.51 & 3.57 & & \\
\hline $\mathrm{Eu}$ & 0.59 & 0.38 & 0.99 & 0.53 & 0.54 & 0.61 & & \\
\hline $\mathrm{Gd}$ & 2.60 & 3.61 & 4.77 & 2.83 & 2.87 & 3.89 & & \\
\hline $\mathrm{Tb}$ & 0.62 & 0.79 & 0.94 & 0.62 & 0.65 & 0.81 & & \\
\hline Dy & 5.01 & 6.09 & 6.80 & 4.78 & 5.10 & 5.92 & & \\
\hline Ho & 1.16 & 1.41 & 1.59 & 1.16 & 1.24 & 1.42 & & \\
\hline Er & 3.35 & 3.97 & 4.66 & 3.47 & 3.66 & 4.25 & & \\
\hline $\mathrm{Tm}$ & 0.53 & 0.60 & 0.71 & 0.56 & 0.56 & 0.67 & & \\
\hline $\mathrm{Yb}$ & 3.53 & 3.66 & 4.86 & 3.48 & 3.70 & 4.67 & & \\
\hline $\mathrm{Lu}$ & 0.49 & 0.50 & 0.69 & 0.50 & 0.52 & 0.67 & & \\
\hline
\end{tabular}


Table 2: Whole-rock $\mathrm{Sr}$ and $\mathrm{Nd}$ isotopic composition of the "spinifex" unit (sample MV9).

\begin{tabular}{lrlr}
\hline $\mathrm{Rb}(\mathrm{ppm})$ & 222.02 & $\mathrm{Sm}(\mathrm{ppm})$ & 2.51 \\
$\mathrm{Sr}(\mathrm{ppm})$ & 61.08 & $\mathrm{Nd}(\mathrm{ppm})$ & 12.12 \\
${ }^{87} \mathrm{Rb}(\mu \mathrm{mol})$ & 0.72305 & ${ }^{147} \mathrm{Sm} /{ }^{144} \mathrm{Nd}$ & 0.1253 \\
${ }^{86} \mathrm{Sr}(\mu \mathrm{mol})$ & 0.06842 & ${ }^{143} \mathrm{Nd} /{ }^{144} \mathrm{Nd}$ & 0.512066 \\
${ }^{87} \mathrm{Rb} /{ }^{86} \mathrm{Sr}$ & 10.5681 & $2 \sigma$ & 0.000008 \\
${ }^{87} \mathrm{Sr} /{ }^{86} \mathrm{Sr}$ & 0.776134 & $\left({ }^{143} \mathrm{Nd} /{ }^{144} \mathrm{Nd}\right)_{\mathrm{t}}$ & 0.511797 \\
${ }^{2 \sigma}$ & 0.000014 & $\mathrm{ENd}_{(\mathrm{t})}$ & -8.2 \\
$\left({ }^{87} \mathrm{Sr} /{ }^{86} \mathrm{Sr}\right)_{\mathrm{t}}$ & 0.7265 & $\mathrm{~T}_{\mathrm{DM}}(\mathrm{Ma})$ & 1865 \\
\hline
\end{tabular}

CHUR composition used to calculate $\varepsilon_{\mathrm{Nd}}$ values is ${ }^{143} \mathrm{Nd} /{ }^{144} \mathrm{Nd}$ $=0.512638$ and ${ }^{147} \mathrm{Sm} /{ }^{144} \mathrm{Nd}=0.1967$; the decay constant is $6.54 \times 10^{-12}$; $\mathrm{Nd}$ model ages are calculated using ${ }^{143} \mathrm{Nd} /{ }^{144} \mathrm{Nd}=$ 0.511580 for the depleted mantle; $\left({ }^{87} \mathrm{Sr} /{ }^{86} \mathrm{Sr}\right)_{\mathrm{t}},\left({ }^{143} \mathrm{Nd} /{ }^{144} \mathrm{Nd}\right)_{\mathrm{t}}$ and $\varepsilon \mathrm{Nd}_{(\mathrm{t})}$ calculated at $330 \mathrm{Ma}$. 